\title{
Bronze Age to Medieval vegetation dynamics and landscape anthropization in the central pre- Pyrenees
}

\author{
Valentí Rull ( $\square$ vrull@csic.es ) \\ Botanic Institute of Barcelona (CSIC) \\ Teresa Vegas-Vilarrúbia \\ University of Barcelona \\ Juan Pablo Corella \\ Université Grenoble Alps \\ Blas Valero-Garcé \\ Pyrenean Institute of Ecology (CSIC)
}

\section{Research Article}

Keywords: Late Holocene, Pyrenees, palynology, vegetation dynamics, land use, anthropization

Posted Date: February 12th, 2021

DOI: https://doi.org/10.21203/rs.3.rs-142567/v2

License: (c) (i) This work is licensed under a Creative Commons Attribution 4.0 International License. Read Full License 


\title{
Bronze Age to Medieval vegetation dynamics and landscape anthropization in the central pre-Pyrenees
}

\author{
Valentí Rull1* ${ }^{*}$, Teresa Vegas-Vilarrúbia ${ }^{2}$, Juan Pablo Corella ${ }^{3}$, Blas Valero-Garcés ${ }^{4}$ \\ ${ }^{1}$ Botanic Institute of Barcelona (CSIC), Passeig del Migdia s/n, 08038 Barcelona, Spain \\ ${ }^{2}$ Department of Evolutionary Biology, Ecology and Environmental Sciences, University of \\ Barcelona, Av. Diagonal 645, 08028 Barcelona, Spain \\ ${ }^{3}$ Université Grenoble Alpes, CNRS, IRD, Grenoble INP, IGE, 38000 Grenoble, France \\ ${ }^{4}$ Pyrenean Institute of Ecology (CSIC), Av. Montañana 1070C, 50820 Zaragoza, Spain \\ *Corresponding author: Email vrull@csic.es
}

\section{Highlights}

- Palynological analysis of Lake Montcortès varved sediments (1100-770 BCE)

- Unexpected Iron Age (770 BCE), rather than Medieval, landscape anthropization

- Shifting land use and variable human pressure until the late Roman Period (770-300 CE)

- Decrease of anthropogenic influence during the Migration Period (300-600 CE)

- Further exacerbation of human activities during the early Medieval Period (600-800 CE)

- A possible general anthropization pattern for the central Pre-Pyrenees? 


\section{Abstract}

The varved sediments of Lake Montcortès (central Pre-Pyrenees) have provided a continuous high-resolution record of the last ca. 3000 years. Previous chronological and sedimentological studies of this record have furnished detailed paleoenvironmental reconstructions. However, palynological studies are only available for the last millennium, when the landscape around the lake had already been transformed by humans. Therefore, the primeval vegetation of Montcortès and the history of its anthropogenic transformations remains unknown. This paper presents a palynological analysis of the interval between the Late Bronze Age and the Early Medieval period, aimed at recording the preanthropic conditions, the anthropization onset and the further landscape transformations. During the Late Bronze Age (ca. 1100 BCE to 770 $B C E)$, the vegetation did not show any evidence of human impact. The decisive anthropogenic transformation of the Montcortès catchment vegetation and landscape started at the beginning of the Iron Age (770 BCE) and continued during Roman and Medieval times in the form of recurrent burning, grazing, cultivation, silviculture and hemp retting. Some intervals of lower human pressure were recorded, but the original vegetation never returned. The anthropization that took place during the Iron Age did not cause relevant changes in the sediment yield to the lake, but a significant limnological shift occurred, as manifested in the initiation of varve formation, a process that has been continuous until today. Climatic shifts seem to have played a secondary role in influencing vegetation and landscape changes. These results contrast with previous inferences of low anthropogenic impact until the Medieval Period, at a regional level. It could be interesting to verify whether the same pattern - i.e., Iron Age anthropization and Early Medieval intensification of human pressure - may be a recurrent pattern for mid-elevation Pyrenean landscapes below the tree line.

Keywords: Late Holocene, Pyrenees, palynology, vegetation dynamics, land use, anthropization 


\section{Introduction}

Varved - i.e., annually laminated - lake sediments are exceptional paleoecological archives, as they provide well-dated past records of annual to seasonal resolution, thus yielding long-term time series able to bridge the gap between ecology and paleoecology (Rull, 2014). These records are able to improve our understanding of ecological responses to changing climates and human disturbance patterns, which are needed for more reliable predictions of ecological trends under future environmental change. Conditions for the formation of annually laminated sediments - i.e., marked seasonality in climate and sedimentary input, and the presence of an anoxic/hypoxic hypolimnion - are more frequent in northern temperate areas, such as for example, in northern and central Europe (O'Sullivan, 1983; Ojala et al., 2012; Zolitschka et al., 2015; Valero-Garcés and Corella, 2018; Ramisch et al., 2020). This type of lake is less common in the Mediterranean region, which enhances the relevance of the few existing representatives as singular paleoenvironmental records. On the Iberian Peninsula, there are five known lakes with continuous or discontinuous varved Holocene intervals that are known, all of which are in karstic settings (Fig. 1). Among them, Lake Montcortès holds the longest and a more continuous varved sequence, which encompasses approximately the last three millennia (Corella et al., 2016, 2019), and has been the most studied of these lakes from paleoclimatic and paleoecological perspectives. These studies have shown that human activities have been the main driver of vegetation and landscape change and have significantly influenced the sedimentary patterns during the last millennium (Corella et al., 2011a, 2012, 2014; Rull et al., 2011; Scussolini et al., 2011; Rull and Vegas-Vilarrúbia, 2014, 2015; Trapote et al., 2018b; Vegas-Vilarrúbia et al., 2018). However, the eventual anthropogenic influence that occurred during the former ca. 2000 years (Late Bronze Age to Early Medieval Period) remains unknown and constitutes the main target of this study.

Studies of the varved sediments of Lake Montcortès have provided high-resolution paleoclimatic reconstructions for the last three millennia. Especially noteworthy are studies on heavy rainfall (HR) variability and on sediment yield (SY) trends to the lake, in relation to climate and human activities. Corella et al. (2016) found that extreme HR events were correlated with negative phases of the Mediterranean Oscillation (MO). During the IberoRoman Humid Period (IRHP; 650 BCE-350 BCE) HR events were highly variable and were characterized by a marked seasonality (Fig. 2). The Migration Period (300 CE-570 CE), which was characterized by the decline of the Western Roman Empire and the widespread invasion of its territories by Barbarian cultures, was a period of exceptionally low frequency of $H R$ events due to the persistent positive-like MO mode that occurred over centennial time scales. The Medieval Climate Anomaly (MCA; 900 CE-1300 CE) was again a phase of large hydroclimatic variability but with HR events generally more intense than in the IRHP, whereas the Little Ice Age (LIA; 1300 CE-1850 CE) was characterized by more stationary HR conditions. During the Industrial Period (IP; after $1850 \mathrm{CE}$ ), a significant increase in the HR frequency occurred, with a subsequent decline in the $20^{\text {th }}$ century. The SY variability in Lake Montcortès has been affected by flood variability and human land use. According to Corella et al. (2019), during the IRHP, the reduced SY was due to low flood intensity and low human impact in the watershed (Fig. 2). Unfortunately, no vegetation reconstructions are available for this time period to evaluate the potential effects of landscape disturbance (deforestation, cultivation, erosion) on SY. The lowest SY values occurred during the Migration Period, coinciding with minimum HR estimates. The SY increase recorded during the $8^{\text {th }}$ to $14^{\text {th }}$ centuries was related to higher human pressure, as manifested in forest clearing by fire, and extensive cultivation and grazing practices. This period also coincided with the highest frequency of flooding events (HR). The significant decline observed during the $14^{\text {th }}$ century was attributed to reduced human pressure due to depopulation of the region around the lake. The low SY values during the Modern Age contrast with the intensification of human activities and were attributed by 
Corella et al. (2019) to the abrupt decrease in HR events. The rise in SY values during the $19^{\text {th }}$ century was linked to an increase in extreme runoff events and an increase in demographic pressure, whereas a significant reduction in both of these forcings was used to explain the reduced SY values during the $20^{\text {th }}$ century. In agreement with these sedimentological observations, a recent review of paleoecological evidence suggested that human pressure on Pyrenean landscapes was low until the period 4000-2000 cal yr BP (2050 BCE to 50 CE) and that the main driver of landscape change was climate until Medieval times, when human activities began to take the lead (González-Sampériz et al., 2017).

The first palynological analyses of Lake Montcortès sediments accounted for roughly the last millennium (780 CE to $1920 \mathrm{CE}$ ), at multidecadal resolution (Rull et al., 2011). A further study increased the resolution of the last ca. 500 years (1420 CE to $2013 \mathrm{CE}$ ) to the subdecadal scale and added the last century, which was absent in previous studies (Trapote et al., 2018b). These time intervals were characterized by a dominant anthropogenic forcing, mainly by burning, cultivation and grazing, from 780 CE onwards (Rull and Vegas-Vilarrúbia, 2015; Montoya et al., 2018). However, the first signs of human disturbance remained unnoticed due to the lack of palynological records prior to the $8^{\text {th }}$ century (Fig. 2). Recent improvements in the age-depth model by detailed varve counting have provided a continuous sequence encompassing the last ca. 2800 years (Corella et al., 2016, 2019), which have extended the potential palynological record to approximately $750 \mathrm{BCE}$, thus increasing the possibility of recording the first steps of human settlement of the Montcortès catchment and the eventual influence on landscape dynamics. As noted above, Corella et al. (2019), based on sedimentary features, inferred low human impact for this time lapse (Fig. 2), roughly corresponding to the Ibero-Roman Humid Period (IRHP). However, humans were already present in the region by those times, which last from the Late Bronze Age to the end of the Visigoth domination, which occurred during the Early Medieval Period.

According to the available archaeological evidence, humans have inhabited the region around Lake Montcortès since at least the beginning of the Bronze Age (1800 to $700 \mathrm{BCE}$ ). This evidence includes numerous megalithic constructions (dolmens), cave dwellings and other archaeological sites with skeletons, ceramics, artifacts, charcoal and a diversity of materials and structures that provide evidence of regular human settlement and activities, such as burial, food storage and salt extraction from groundwater springs, among others (Panyella, 1944; Clop and Faura, 1995; Simon and Vicente, 2002; Piera, 2013; Piera et al., 2013). The earliest radiocarbon age available corresponds to a human skeleton dated to $3770 \mathrm{cal}$ yr BP (approximately $1820 \mathrm{BCE}$ ), suggesting that the region around Lake Montcortès was populated during the Early Bronze Age, which is consistent with ceramic stylistic features (Piera, 2013, Piera et al., 2013). Therefore, humans were already present in the region at the beginning of the Lake Montcortès varve-dated interval (750 BCE or 2700 yr BP); however, when and how they began to transform the landscape remains unknown. The available historical records suggest that, in contrast with southernmost lowlands, Iberian cultures did not colonize the Montcortès region, which was inhabited by marginal populations until the incoming of the Roman Empire (Cots, 2005).

In this paper, a palynological analysis of the unstudied interval (750 BCE to $1170 \mathrm{CE}$ or $2700 \mathrm{yr}$ $\mathrm{BP}$ to $780 \mathrm{yr} \mathrm{BP}$ ) is performed, which is aimed at (i) characterizing the preanthropic vegetation of the Montcortès region; (ii) recording the timing and nature of the first large-scale human disturbance; and (iii) documenting the effects of human activities and eventual environmental changes on vegetation and landscape trends, from the Late Bronze Age to the Early Medieval Period. This analysis would also enable disentangling of the effects of natural and anthropogenic ecological forcings by allowing a comparison of paleoecological reconstructions before and after extensive anthropogenic transformations. 


\section{Study site}

Lake Montcortès (Fig. 3) is located at 42 $19^{\prime} 50^{\prime \prime} \mathrm{N}-0^{\circ} 59^{\prime} 41^{\prime \prime}$ and $1027 \mathrm{~m}$ elevation, in the south-central Pyrenean flank, in the historical region of Pallars (Catalonia, NE Spain). Geologically, the lake lies in a karstic terrain characterized by Triassic limestones, marls and evaporates, and Oligocene carbonatic conglomerates. Triassic oophytes outcrop mainly in the south and Quaternary lacustrine sediments surround the present-day waterbody (Corella et al., 2011a; Gutiérrez et al., 2012). The climate data for the 1961-1990 period from the nearby La Pobla de Segur weather station (Fig. 1), which is situated at approximately $9 \mathrm{~km}$ to the south at $513 \mathrm{~m}$ elevation, show that the annual average air temperature of the area is $12.8^{\circ} \mathrm{C}$, ranging from $2.9^{\circ} \mathrm{C}$ in January to $23.2{ }^{\circ} \mathrm{C}$ in July. The total annual precipitation is $669 \mathrm{~mm}$. February is the driest month $(33.4 \mathrm{~mm})$, and May is the wettest month $(88.4 \mathrm{~mm})$. The maximum and minimum temperatures recorded at this location were 41 and $-20^{\circ} \mathrm{C}$, respectively. The maximum daily precipitation recorded was $138 \mathrm{~mm}$. The predominant direction of the wind is SW during fall and winter, shifting to SSE during spring and summer (Rull et al., 2017).

Lake Montcortès is kidney-shaped and small, with a diameter of $400-500 \mathrm{~m}$, a total surface area of $0.14 \mathrm{~km}^{2}$, and a maximum depth of $32 \mathrm{~m} \mathrm{(Fig.} \mathrm{3).} \mathrm{The} \mathrm{watershed} \mathrm{is} \mathrm{also} \mathrm{small}$ (approximately $1.4 \mathrm{~km}^{2}$ ), with a few intermittent small creeks and scattered springs, and the lake is fed primarily by groundwater. The lake was first considered to be meromictic (Camps et al., 1976), but some mixing events (holomixis) were occasionally observed in the further studies (Modamio et al., 1988). A recent high-resolution study of the Montcortès sediments encompassing the last 500 years has shown that the lake cannot be unequivocally characterized as meromictic, as water mixing and hypolimnion oxygenation variations have occurred through history (Vegas-Vilarrúbia et al., 2018). At present, the lake is thermally stratified during most of the year, except in winter when mixing events occur (Trapote et al., 2018a).

Lake Montcortès lies near the altitudinal boundary between submontane and montane vegetation belts, which is situated at approximately 800-1000 $\mathrm{m}$ in the Pyrenees, depending on local conditions (Vigo and Ninot, 1987). Around this transitional boundary, the following four major forest formations representing the upper Mediterranean, the submontane and the montane stages occur: (i) Mediterranean sclerophylous forests of Quercus rotundifolia, (ii) submontane deciduous oak forests of Quercus pubescens and Q. subpyrenaica, (iii) submontane conifer forests of Pinus nigra subsp. salzmannii and (iv) montane forests of Pinus sylvestris. Pastures, meadows and crops are the main herbaceous vegetation types, whereas scrub, abandoned crops and badlands are minority types present. Locally, the lake is surrounded by an almost continuous belt of aquatic and semiaquatic vegetation dominated by Phragmites australis, with Typha domingensis and Cladium mariscus also found. The local and regional flora and vegetation around Lake Montcortès have been described and mapped in detail elsewhere (Rull et al., 2011; Mercadé et al., 2013; Trapote et al., 2018b). The forest stands around the lake are dominated by deciduous Quercus (Fig. 3).

The present-day landscape features are the result of centuries of human disturbance, as documented by a combination of historical and palynological records (Rull et al., 2011; Rull and Vegas-Vilarrúbia, 2015; Trapote 2018b; Montoya et al., 2018). The available record dates back to the $8^{\text {th }}$ century (Early Medieval Period), shortly before the Carolingian conquest, and begins with intensive forest burning and shifting cultivation. Since then, several phases of cultivation, grazing, forest recovery and further burning have been documented and related to demographic/cultural shifts and climate changes (Fig. 2). The times of higher human impact ( $9^{\text {th }}$ to $14^{\text {th }}$ centuries and $16^{\text {th }}$ to $18^{\text {th }}$ centuries) were characterized by enhanced cultivation 
and intensive grazing. During the first of these two phases, the main cultivated plants were wheat/oat (Triticum/Avena) and rye (Secale cereale). During the second phase, hemp (Cannabis sativa) cultivation, and possibly retting, notably increased and peaked in the mid$19^{\text {th }}$ century, when an abrupt decrease was recorded. Phases of lower human impact were characterized by forest recovery and occurred at the end of the Medieval Period ( $15^{\text {th }}$ century) and just after the abandonment of hemp cultivation/retting (mid- $19^{\text {th }}$ century). The first forest recovery was related to a regional depopulation by wars, black pest and human migration to the southern lowlands due to the LIA cooling. This was the Medieval crisis that ended the feudal system and gave way to the Modern Age (Fig. 2). The second forest recovery was linked to another demographic decline due to the industrial revolution, which favored field abandonment and migration from rural to urban areas.

\section{Materials and methods}

\subsection{Core sampling and dating}

The samples studied in this paper are from two cores (MON04-3A-1K and MON04-4A-1K) retrieved during the first coring campaign carried out in Lake Montcortès (April 2004), using a Kullenberg corer platform from the Limnological Research Center (LRC) of the University of Minnesota, Minneapolis (USA). The cores were preserved at $4{ }^{\circ} \mathrm{C}$ in the Pyrenean Institute of Ecology (IPE) in Zaragoza (Spain). The core intervals for this study were selected to represent the unstudied time period between approximately 750 BCE (2700 yr BP) and 780 CE (1170 yr $\mathrm{BP})$, according to the varve chronology of Corella et al. $(2014,2016)$. This process resulted in the selection of drive 4 for core MON04-3A-1K and drives 4 and 5 for core MON04-4A-1K (Fig. 3). Following Corella et al. (2017) and Trapote et al. (2018b), samples were taken from the varved intervals, avoiding turbidites, since they are formed by allochthonous clastic material deposited within hours or days, as a result of episodic runoff events. A total of 61 samples (P1 to P61), with an average volume of $1.55 \mathrm{~cm}^{-3}$ (range: 1.1 to $1.9 \mathrm{~cm}^{-3}$ ) and an average weight of $1.939 \mathrm{~g}$ (range: 1.256 to $2.681 \mathrm{~g}$ ), were taken.

\subsection{Palynological analysis}

The core samples were processed for palynological analysis at the Laboratory of Paleoecology (PALAB) of the Institute of Earth Sciences Jaume Almera (ICTJA) in Barcelona (Spain) using $\mathrm{HCl}$, $\mathrm{KOH}$, and HF digestions and acetolysis (Moore et al., 1991; Bennett and Willis, 2001), with previous spiking with Lycopodium tablets (batch 124961; 12,542 spores/tablet). The samples were mounted and stored in glycerin jelly. The identification procedure followed the previous palynological surveys developed for Montcortès sediments (Rull et al., 2011, 2017; Rull and Vegas-Vilarrúbia, 2014, 2015; Trapote et al., 2018b; Montoya et al., 2018) and the PALAB pollen reference collection. The pollen counting procedure followed the criteria of Rull (1987), namely, a minimum pollen sum (including only pollen types) of 200 grains and the saturation of diversity. Some non-pollen palynomorphs (NPP) such as algae remains (Botryococcus, Pediastrum), spores of coprophilous fungi (Sporormiella, Sordaria) and charcoal particles larger than $5 \mu \mathrm{m}$ were also identified and counted. Diagrams were plotted and zoned with psimpoll 4.27 using the Optimal Splitting by Information Content (OSIC) method (Bennett, 1996). The pollen groups were defined according to present-day vegetation types. The interpretation of the pollen diagrams was based on the previous studies referenced above and a 2-year (20142015) modern-analog study using sediment traps (Rull et al., 2017). 


\section{Results}

\subsection{Age-depth model}

The age-depth model resulted from the straightforward plotting of the composite depths and varve ages of the samples taken for pollen analysis (Fig. 4). The eight basal ages of the sequence (drive 5 of core MON04-4A-1K) were taken in an interval of nonbiogenic laminations and could not be dated by varve counting. Assuming linear accumulation rates similar to the overlying samples of the same drive, the basal age was estimated to be approximately 1100 BCE or $3050 \mathrm{yr}$. BP. The global average difference between contiguous samples was approximately 10 years (range: $0.3-31.5$ ), but there was a significant difference between cores. In core MON04-3A-1K, the average difference is approximately 4 years (range: 0.3 to $7 \mathrm{yrs}$.; subdecadal resolution), whereas in core MON04-4A-1K, the average difference is approximately 14 years (range: 1.25 to 31.5 yrs.; subdecadal to multidecadal resolution).

\subsection{Vegetation and landscape dynamics}

A total of 55 pollen and fern spore types were identified and counted. The pollen diagram (Fig. 5 ) depicts those that are representable in percentage with respect to the pollen sum. The remaining types were too scarce and scattered to be depicted individually and were grouped in the category "others", which contain the following types: Allium, Apiaceae, Castanea, Centaurea, Cerastium-t, Cladium, Echium, Euphrasia-t, Fabaceae (others), Fraxinus, Helianthemum, Ilex, Juglans, Lathyrus-t, Linum, Lonicera, Myriophyllum, Olea, Paronychia-t, Pedicularis-t, Populus, Potamogeton, Prunus-t, Rubia, Salix, Taxus, Thymus-t, Tilia, Urtica and Vitis. Fern spores are represented together in the diagram, but they are largely dominated by psilate monoletes, with a few verrucate representatives.

Overall, the diagram is dominated by Quercus (deciduous and evergreen) and Pinus, which represent the same tree taxa that dominate the present-day regional vegetation (Mercadé et al., 2013) and the modern pollen assemblages (Rull et al., 2017). Therefore, these forests have been dominant during the time period represented in this study, although they have experienced significant variations in their compositions. Other pollen types are less abundant and more variable, likely representing the local vegetation changes that occurred in the small catchment around the lake (Rull et al., 2017), where the landscape has been intensively modified by human activities. Indeed, the frequent occurrence of cultivated plants and weeds (Rull and Vegas-Vilarrúbia, 2015), the almost continuous presence of coprophilous spores (Sporormiella, Sordaria) indicative of local grazing (Montoya et al., 2018) and the abundance of charcoal particles derived from fires, indicates that human disturbance has been nearly constant, except for the period before $2700 \mathrm{BP}$ (750 BCE). To follow the vegetation and landscape changes in more detail, the pollen diagram has been subdivided into six significant pollen zones (Fig. 5). Given the nature of the evidence provided by the present pollen analysis and to avoid circularity - e.g., inferring past climatic trends from pollen evidence and then trying to assess the response of vegetation to the assumed climatic shifts derived in this waythe interpretation of these pollen zones is addressed first in terms of vegetation shifts, fire incidence, cropping and grazing. Potential relationships with other environmental or anthropogenic drivers will be addressed later, in the general discussion, using independent evidence from the corresponding fields (climatology, sedimentology, limnology, archaeology, and history). 
The regional forests were dominated by Quercus, with a later increase in the deciduous species at the expense of the evergreen species. Pinus was in its lowest values, except for a peak at ca. 2900 BP (950 BCE). Other than these major components, only Alnus and Corylus show relevant abundances in this zone. These taxa have not been reported in the present vegetation of the Montcortès region, but their species Alnus glutinosa (black alder) and Corylus avellana (common hazel) are important components of the most common gallery forests (known as Alnetum catalaunicum) along rivers and around lakes in the central Pyrenees above $600-800 \mathrm{~m}$ elevation (Folch et al., 1984). Therefore, the zone around Lake Montcortès was likely covered by this type of riverine forest. Pollen types from plants indicating cropping and/or grazing activities were almost absent, except for some scattered grains of cereals and the weed Plantago (Rull and Vegas-Vilarrúbia, 2015). The plant cover, as inferred from the total pollen influx, was maximum. Coprophilous fungi (Sporormiella, Sordaria) were almost absent, and charcoal particles showed minimum values, indicating very low anthropogenic disturbance. Botryococcus remains, which represent plankton communities, were also negligible, probably due to the low amount of nutrients released to the lake from the catchment, which remained virtually undisturbed. This pollen zone coincides with the interval of nonbiogenic varves in the sediment (Corella et al., 2011a, 2016). In summary, the vegetation present during the Late Bronze Age may be considered virtually untouched, in terms of human disturbance, and could therefore be viewed as the most pristine vegetation of the Montcortès region during the studied interval.

\section{Pollen Zone 2: 2720 BP (770 BCE) to $2130 \mathrm{BP}$ (180 BCE), Iron Age}

The evergreen Quercus species were dominant in the regional forests, whereas Pinus and the deciduous Quercus have lower values, with the first showing a maintained increase throughout the zone. The Alnus-Corylus riverine forests disappeared from around the lake, although Corylus remained in moderate values. The vegetation of the watershed became more herbaceous, with small increases in wild Poaceae, cereal crops and taxa associated with local grazing, such as Artemisia and other Asteraceae (Mercadé et al., 2013). This zone may be considered the beginning of large-scale human disturbance occurring in the Montcortès watershed, initiated by an outstanding fire event peak at ca. 2630 BP (680 BCE) that drastically reduced the plant cover of the lake catchment, as suggested by the major decline in total pollen influx. The beginning of strong local human pressure, including fires and intensive grazing, is confirmed by the appearance of Sporormiella and Sordaria and the continuity of charcoal, which remained through the entire zone. The peak and ensuing presence of Botryococcus may be the consequence of lake fertilization resulting from the increase in edaphic organic matter due to grazing and the enhanced runoff favored by landscape opening. This sudden and intense regime shift in both the lake and its surroundings due to human pressure coincided with the initiation of the biogenic varves (Corella et al., 2016, 2019). This zone has two subzones ( $2 a$ and $2 b$ ), with the boundary situated at approximately 400-420 BCE. Subzone 2 a roughly coincides with the first phase of the Iron Age (I) and is characterized by a degraded vegetation around the lake, which is a consequence of the first human disturbance event. Subzone $2 \mathrm{~b}$ represents an increase in land use, mainly grazing and cultivation, initiated during the second phase (II) of the Iron Age.

\section{Pollen Zone 3: $2130 \mathrm{BP}$ (180 BCE) to $1690 \mathrm{BP}$ (260 CE), Iron Age to Roman Period}

A significant change in the regional forest composition occurred in this zone, as Pinus replaced the evergreen Quercus species as the dominant trees. The deciduous Quercus maintained values similar to Zone 2 . Around the lake, the palynological indicators of cropping and grazing 
declined and Corylus increased for prolonged period. This occurred the beginning of the Roman period, coinciding with a decrease in charcoal and the coprophilous fungi, an increase in the plant cover and the local disappearance of Botryococcus. This combination suggests a decline in human pressure, which continued until the mid-Roman period. It is possible that the growing of Corylus stands was favored by humans, as hazelnuts were very appreciated by Roman people (Cots, 2005), who used to collect these fruits from the wild on wet sites (PeñaChocarro et al., 2019). At the end of the zone, Corylus disappeared again from the catchment, and the indicators of cropping and grazing (Artemisia, cereals and Plantago) increased, accompanied by Juniperus and Buxus. The replacement of Corylus stands with cultivated plants was mediated by significant peaks of fire, Sporormiella and Sordaria initiated at ca. 1790 BP (240 CE) and coeval with a short plant cover decline, indicating the return of anthropogenic pressure by the mid-late Roman period. Such return would be consistent with the increase in the shrubs Juniperus and Buxus as, in the Montcortès region, the combination of Juniperus communis (common juniper) and Buxus sempervirens (common box) is frequent in shrublands growing on deforested areas and in forest clearings on calcareous soils (Carreras et al., 20052006). This zone can also be subdivided into two subzones ( $3 \mathrm{a}$ and $3 \mathrm{~b}$ ), with the boundary at approximately $100 \mathrm{CE}$. Subzone $3 \mathrm{a}$ is characterized by the increase in Corylus, and Subzone $3 \mathrm{~b}$ is marked by a second increase in grazing and cereal cultivation, this time accompanied by the expansion of Juniperus-Buxus shrublands.

Pollen Zone 4: 1690 BP (260 CE) to 1370 BP (580 CE), Roman Period to Early Medieval Period

The regional forest situation did not change significantly compared to Zone 3 , with the dominance of Pinus (albeit with lower percentages than in the former zone) followed by deciduous and evergreen Quercus. A temporary but significant decrease in Pinus at the beginning of this zone coincided with the occurrence of the maximum values of some anthropogenic indicators (mostly Cerealia, Artemisia and Plantago), suggesting an expansion of arable and grazing land at the expense of pine forests and/or an increase in exploitation of pine forests for wood. The significant decrease in the charcoal values suggests that pines could have been cut down instead of burnt, a common practice during the Roman occupation of the Pallars region (Cots, 2005). The landscape around the lake underwent relevant changes. Gallery forests (Corylus) did not reappear again and the taxa indicator of cropping and grazing attained their maxima, which coincided with the maxima of shrubs such as Juniperus and Buxus. This zone represented a phase of maximum land use of the Montcortès catchment, in terms of cultivation and forest exploitation, compared to former times, when grazing and fires were more dominant. The synchronous declines in coprophilous fungi and fires, together with a plant cover increase from the beginning of the zone coincided with significant increases in cereal cultivation - notably Secale, Triticum and Avena, with Plantago and Artemisia as weeds (Rull and Vegas-Vilarrúbia, 2015) - between the Late Roman period and the first part of the Early Medieval period. These human activities were at their maximum by ca. 1650 BP (300 CE) and began to slowly decline after, coinciding with a similar gradual decline in fires and a progressive increase in plant cover. This phase of declining anthropogenic pressure has been called the Migration Period and represented the end of the Roman occupation and the progressive colonization of the land by barbarian peoples, in this case, the Visigoths. At the end of the zone, a short-living increase in Betula suggests that this well-known secondary colonizer of forest clearings in mountain and high-latitude biomes (Dubois et al., 2020) could have colonized the open areas left by former shrublands and crops/pastures.

\section{Pollen Zone 5: 1370 BP (580 CE) to 1190 BP (760 CE), Early Medieval Period}

The regional forests underwent a significant shift in composition, with the deciduous Quercus species almost disappearing and the dominance of the evergreen species of the same genus 
increasing. In analogy with present conditions, this could imply the increased opening of the landscape around the lake by the removal of the surrounding forests dominated by deciduous Quercus species (Fig. 3). This selective deforestation may have led to minimal plant cover values, as supported by the sudden and significant drop in the pollen influx. The former crops notably declined and were replaced by wild Poaceae and Cannabis. The increase in

Sporormiella and Sordaria together with the mentioned decline in plant cover and fires suggest enhanced grazing activities and an open landscape around the lake, devoid of plant fuel to burn (or, alternatively, with decreasing burning practices). The dominance of Cannabis pollen may be the result of either in situ cultivation, hemp retting, or both. These possibilities have already been discussed in previous papers dealing with the last millennium, where Cannabis pollen reached values up to $40-60 \%$, which seems to be indicative of retting (Rull et al., 2011; Scussolini et al., 2011; Trapote et al., 2018b). Hemp cultivation around Lake Montcortès has been considered unlikely due to its elevation. Indeed, the maximum amount of Cannabis pollen in lake sediments occurred in the mid- $19^{\text {th }}$ century, likely as a result of retting activities using the hemp cultivated and transported from several lowland villages (Rull and VegasVilarrúbia, 2014). Additional evidence for retting instead of in situ cultivation is the peaking of algae remains such as Botryococcus and Pediastrum, probably as a result of lake water fertilization by the decaying hemp plants introduced into the lake for retting purposes (Rull and Vegas-Vilarrúbia, 2014; Trapote et al, 2018b). A possibility that should not be ruled out is that the Cannabis pollen came from regional sources, as has been suggested by modern sedimentation surveys, where this pollen attained significant percentages in the absence of local cultivation and retting (Rull et al., 2017).

\section{Pollen Zone 6: 1190 BP (760 CE) to 1130 BP (820 CE), Early Medieval Period}

The regional forest composition was very similar to that of the former zone and the landscape around the lake remained totally open, just as in the former zone. The main difference was the significant decline in Cannabis pollen and its replacement with wild grass pollen that, together with increases of Rumex and Urtica, suggests the extensive development of meadows and pastures (Rull and Vegas-Vilarrúbia, 2015). Such development is consistent with other grazing indicators, such as Sporormiella and Sordaria, and with the incoming of Glomus, an indicator of increased watershed erosion and runoff into the lake (Montoya et al., 2018). The plant cover around the lake was at the minimum, which favored enhanced erosion, and fires were almost absent, probably for the same reasons as the former zone, that is, forest exploitation by logging instead of burning. This zone coincides chronologically and palynologically with the base of zone M-1, dated to 1170-1000 BP (780-950 CE), of a previous paleoecological study embracing roughly the last millennium (Rull et al., 2011).

\section{Discussion}

The palynological results disclosed in this paper furnished evidence regarding the preanthropic vegetation of Lake Montcortès region during the period studied, the beginning of intensive human disturbance and the type and nature of further vegetation and landscape transformations according to the different land uses that occurred between the Late Bronze Age and the Early Medieval period. The discussion of these trends and events, as well as the possible environmental and sedimentological factors involved, is organized chronologically using the local prehistoric and historical subdivisions of the Pallars region (Cots, 2005). A summary of the multidisciplinary information used in this discussion is provided in Fig. 6 . At the end of this discussion, the anthropization trends of Montcortès are placed in the context of the southern-central Pyrenees to provide a more regional picture. 


\subsection{Late Bronze Age: nearly pristine landscapes}

Before large-scale human impact, the vegetation around Lake Montcortès was fully forested. The lake was surrounded by riverine forests composed of Alnus and Corylus, whereas the regional forests were dominated by deciduous Quercus species (probably $Q$. pubescens and $Q$. subpyrenaica, as in the present), followed by evergreen Quercus species (probably $Q$. rotundifolia) and Pinus (possibly P. nigra subsp. salzmannii and $P$. sy/vestris). It is worth noting that the Alnus-Corylus riverine forests have no analogs in the present vegetation of the Montcortès region (Mercadé et al., 2013). It should be remembered that the nonbiological nature of the sedimentary laminations that characterized this time period prevented varve dating, and the dates of the samples analyzed have been extrapolated assuming constant sedimentary rates. Nevertheless, it can be attested that the nearly pristine vegetation and landscape conditions documented above occurred before 2700 BP (750 BCE), which is the oldest date obtained by varve counting and coincides with the end of the Bronze Age. During those times, the human populations in the Pallars region consisted of small isolated groups living in caves and outdoor settlements that subsisted from agriculture, pastoralism (including vertical transhumant practices between lowlands and highlands), hunting and gathering (Cots, 2005). The lack of grazing indicators in the pollen zone corresponding to this time period indicates that the lake watershed was not used for grazing. The small amount of charcoal particles in the same zone could be a background signal from regional, possibly lowland, fires or the manifestation of local occasional visitors with very low impact on the landscape. The scattered occurrence of some pollen grains of cereals and weeds (Plantago) supports this interpretation.

The apparently untouched nature of the Late Bronze Age landscape around Lake Montcortès does not necessarily represent the primeval state before any human disturbance. The lack of sedimentary records older than the Late Bronze Age in this lake prevents us from knowing whether the vegetation of this time period was actually primeval or was the result of an eventual Bronze Age recovery after earlier human modification of the original plant communities. The recovery of older sedimentary records is needed to answer this question.

Regarding potential environmental drivers affecting the vegetation trends in the Montcortès area, no independent information on the environmental and sedimentological features for times before 800 BCE is available for comparison (Corella et al., 2016, 2019). In a broader context, the Late Bronze Age on the northern Iberian Peninsula was characterized by warm climates spiked by short cool events of approximately 0.4 kyr periodicity (Martín-Chivelet et al., 2011). In the absence of significant anthropogenic disturbances, warmer climates may have favored the dominance of regional Quercus forests, characteristic of Mediterranean to submontane stages, which are situated at lower elevations than submontane to montane Pinus forests (Mercadé et al., 2013). Similarly, no information is available on the precise age and origin of the nonbiogenic laminations that characterize the Late Bronze Age in the sediments of Lake Montcortès, but it has been suggested that higher organic matter accumulation would have lowered the $\mathrm{pH}$ in anoxic pore waters, which could have dissolved $\mathrm{CO}_{2}$ particles reaching the sediment-water interface (Corella et al, 2011a).

\subsection{Iron Age: anthropogenic transformation}

The apparently untouched vegetation suddenly disappeared at the beginning of the Iron Age (2720 BP or $770 \mathrm{BCE}$ ) due to anthropogenic burning and the introduction of grazers and some crops, thus creating an open landscape around the lake. This first transformation of the original Montcortès landscape, which occurred during the first phase of the Iron Age, was irreversible, as the Alnus-Corylus gallery forests never returned and the lake catchment was 
submitted to continuous and varied land uses over time. The first consequence of anthropic fires and intensive grazing was a degradation of the catchment vegetation and an abrupt and dramatic reduction in plant cover. This initial landscape anthropization event occurred earlier than previously thought. For example, archaeological evidence was used to support reduced human impact in the Pallars until the Roman period (Cots, 2005), whereas the sedimentological trends from Lake Montcortès were interpreted in terms of low human pressure until Early Medieval times (Corella et al., 2019). As explained in the former section, other montane areas of the central Pyrenees below the tree line were also affected by human practices at the same time, suggesting the possibility of a recurrent pattern of human anthropization for mid-elevations, which should be tested in future studies. In human terms, the situation during the first phase of the Iron Age was similar to that of the Late Bronze Age, except for a more restricted, sometimes inexistent, transhumance between lowlands and highlands (Cots, 2005). Climatically, this phase coincided with the Iron Age Cold Period, characterized by a minimum in solar activity and significant changes in the Atlantic circulation (Martín-Chivelet et al., 2011), coinciding with cold and dry climates in the Mediterranean (Martín-Puertas et al., 2010). HR events reached a maximum, and sediment delivery to the lake also experienced a short but marked increase (Corella et al., 2016, 2019) coeval with the beginning of vegetation degradation and a minimum in vegetation cover. These processes would have caused enhanced erosion rates and increased sedimentation rates. The anthropization event coincided with the onset of biogenic varve formation. It is possible that higher human-induced runoff may have increased the input of carbonate and nutrients, leading to higher epilimnion productivity and the subsequent varve formation (Corella et al., 2011a, 2012). This pattern has also been observed in other Iberian karstic lakes with similar varve formation patterns (Romero-Viana et al., 2008). It has also been suggested that the onset of varve formation coincided with a change in the lake level, from a shallower lake with a carbonate platform and the associated palustrine environments to a deeper lake with a welldeveloped anoxic hypolimnion. This suggestion would be supported by the occurrence of diatom-rich and organic-rich laminae, suggesting high primary productivity and good preservation potential in the deep areas of the lake (Corella et al., 2011a). In this case, the peak of Botryococcus recorded in this study at the beginning of the Iron Age could be due to a combination of both catchment disturbance and lake deepening.

During the second phase of the Iron Age, initiated in $450 \mathrm{BCE}$, the formerly degraded terrains started to be used for cultivation and grazing. By those times, the human populations experienced a significant demographic expansion and began to concentrate in villages. This process was linked to the development of the iron industry, which also contributed to social diversification (Cots, 2005). The climate was warmer and wetter than in the first phase and the $S Y$ remained similar to that of the first phase of the Iron Age. After an initial minimum, the HR events were alternating during this second phase but clearly increased until a maximum occurred at the end of the Iron Age, coinciding with a decrease in grazing and cropping, and human land use, in general. In the regional forests, the change in dominance from Quercus to Pinus initiated at the end of the Iron Age coincided with a cooling, which probably lowered the general vegetation belts.

\subsection{Roman Period: frequent land use changes}

During the Roman domination, the demographic growth continued and, in addition to pastoralism, agriculture and iron mining, new activities were added, such as silviculture, marble quarrying and extensive commerce (Cots, 2005). During this time interval, the Montcortès watershed experienced frequent changes that have been summarized into three phases. During the first phase (70 BCE-100 CE), the catchment was characterized by degraded vegetation with Corylus stands and moderate human pressure, coinciding with a significant 
temperature maximum and minima in HR events and SY. Human pressure was moderate but changed in the second phase (100 CE-260 CE), when all indicators of grazing, cropping and fire increased, this time with the addition of shrublands that colonized the most degraded areas, as the plant cover significantly decreased. Human pressure was increasing, climates remained warm and wet, as was typical from the Roman Warm Period and the Ibero-Roman Warm Period, and HR events and SY experienced significant increases, likely related to the decline in the plant cover. A third phase (260 CE-420 CE) was characterized by maxima in all indicators of human disturbance, which were coeval with a cooling trend and a significant decrease in HR events. Pinus remained dominant over Quercus during all the Roman period, which contrasts with general warmer/wetter climates, which would have favored the reverse situation. It is possible that silviculture practices or forest management, or both, were involved in the relative decline in Quercus forests, which are the closest to the lake.

\subsection{Migration Period and Early Medieval times: hemp industry, meadows and deforestation}

This time interval has not been described in the archaeological and historical literature of the Montcortès region (Cots, 2005) but has been used in previous sedimentological and paleoenvironmental studies (Corella et al., 2016, 2019), as it is a widely recognized historical phase across Europe. According to Marugan and Oliver (2005), the Visigoths established north of the Pyrenees by $420 \mathrm{CE}$ and progressively migrated to the south until approximately $710 \mathrm{CE}$, when they reached the center of the Iberian Peninsula. According to the same authors, the presence of Visigoths in the Pallars region has not been demonstrated, probably due to the lack of studies. It has been suggested that, in the Pallars region, indigenous Iberian societies would have experienced a recovery after the Roman domination. The disintegration of the Roman world was followed by deep transformations in the land use, such as the expansion of bottom-valley agriculture, a significant local mining increase and the development of extensive pastoralism, including horizontal transhumance. Similarly, it seems doubtful that the Muslims fully colonized the Pallars, which was close to the northernmost border of the Iberian Arab empire. During this short period ( $710 \mathrm{CE}-800 \mathrm{CE})$, the region was populated by a mixture of Christian and Muslim cultures (Marugan and Oliver, 2005).

From the point of view regarding vegetation and land use, the evidence provided in this study allows subdividing the Migration Period-Early Medieval times into three well differentiated phases. The first phase corresponds to the Migration Period itself, characterized by the general decline in all indicators of human disturbance until minimum values were reached in $580 \mathrm{CE}$. This process occurred during the Dark Ages Cold Period/Late Antique Little Ice Age, when HR events and SY were minimal or inexistent, and human disturbance was decreasing. During the next phase ( $580 \mathrm{CE}-760 \mathrm{CE}$ ) cereal crops were abandoned and the hemp industry took the lead. As discussed before, it is not clear whether this plant was cultivated around the lake or was transported from lowlands for retting. The increase in temperature corresponding to the Medieval Warm Period (Martín-Chivelet et al., 2011; Moreno et al., 2012) would have favored in situ cultivation, but additional evidence is needed to confirm this point. Hemp retting in Lake Montcortès has been confirmed by previous studies (Rull et al., 2011; Rull and VegasVilarrúbia, 2014; Trapote et al., 2018b). During this phase, the plant cover around the lake, as inferred by the pollen influx, abruptly declines to their minimal values recorded, which may explain the peak in SY and denudation rates recorded in previous studies, likely as a result of enhanced runoff and sediment delivery to the lake (Corella et al., 2019). The situation is similar to other locations from the central Pyrenees, where the onset of intensive and extensive landscape anthropization was recorded in Early Medieval times (González-Sampériz et al., $2017,2019)$. The present study demonstrates that, in the Montcortès region, full anthropization occurred well before these dates, at the beginning of the Iron Age. However, the intensity of the human impact seems to have been at its maximum from the Early 
Medieval times onwards. Regarding the regional forests, Pinus was still dominant and the deciduous Quercus species seems to have been especially affected by human activities and almost disappeared, possibly due to selective deforestation around the lake, where these species once dominated. The third phase (760 CE-820 CE) is similar to the second, except for the abandonment of the hemp industry and the development of grass meadows around the lake. These changes would have been due to cultural reasons, as the climate remained the same as in the former phase.

\subsection{Montcortès anthropization within a regional context}

This section is aimed at highlighting potential elevational patterns in the anthropization of the southern-central Pyrenees over time and at situating the case of Montcortès within such a spatiotemporal context. For this, a brief account of the main archaeological and paleoecological findings is provided.

Archaeological evidence has documented human presence on the central Pyrenees, at elevations of approximately $1000 \mathrm{~m}$, since the last glaciation, followed by an expansion to subalpine and alpine areas during the Younger Dryas. Neolithization started at 5400 BCE (7250 cal yr BP) in elevations up to $1600 \mathrm{~m}$ and extended above this elevation by $3400 \mathrm{BCE}$ ( $5350 \mathrm{cal}$ yr BP), leading to a widespread inception of pastoralism in areas above the tree line (ca. 2300 m) (Rodríguez et al., 2016; Gassiot et al., 2017; González-Sampériz et al., 2019; García Ruiz et al., 2020). Archaeological remains are scarce during the Bronze Age and Iron Age, between approximately 2400 BCE and 300 BCE (4350-2250 cal yr BP), and increase during the Roman occupation and the Medieval Period, when human pressure reached the maximum (Rodríguez et al., 2016; Gassiot and Pèlachs, 2017; Gassiot et al., 2017; González-Sampériz et al., 2017, 2019).

Regarding paleoecological evidence, the reviews by González-Sampériz et al. (2017, 2019), include the study of sediments from ca. 20 lakes situated at different elevations. All these lakes, except one from the lowlands ( $>800 \mathrm{~m}$ ), are in the subalpine and alpine zones (1600 to $2600 \mathrm{~m}$ ), where Pyrenean lakes are more abundant. In the montane zone (800 to $1600 \mathrm{~m}$ ), natural lakes are scarce or inexistent. According to the above reviews, the first signs of anthropogenic deforestation and cereal cultivation were found in the basimontane lowlands (600-700 m elevation) during the Early/Middle Bronze Age (3700 to 3100 cal yr BP). In most subalpine environments between ca. 1600 and $2000 \mathrm{~m}$, human disturbance was low to moderate during the Bronze Age, up to approximately $2700 \mathrm{cal}$ yr BP, and the landscape became highly anthropized during the Iron Age and the Roman occupation, up to approximately 2000 cal yr BP. In subalpine and alpine locations of higher elevation (ca. 2000$2600 \mathrm{~m}$ ), the first signs of anthropization occurred later, during Medieval times (ca. 1200 to $700 \mathrm{cal}$ yr BP). The whole picture suggests a temporal trend of anthropization with elevation, with a few exceptions due to specific local conditions, from the Early/Middle Bronze Age in the lowlands to the Iron Age/Roman Period in the subalpine zone, and the Medieval Period in highlands (Fig. 7). However, there is a gap in this gradient due to the absence of lakes in the montane zone. This paper provides paleoecological information from the lower montane Montcortès record, whose anthropization timing (Iron Age) is more similar to subalpine (Iron Age to Roman Period) than to the nearby lowland environments (Early/Middle Bronze Age).

The combination of archaeological and paleoecological evidence suggests that montane landscapes could have been anthropized at similar times than lower subalpine environments, and therefore, montane and lower subalpine landscape anthropization may have progressed relatively rapidly between the Iron Age and the Roman Period, after a decline in human pressure during the Bronze Age (Fig. 7). We suggest that this elevational diachronism could 
have been a recurrent pattern for mid-elevation environments situated between ca. 1000 and $2000 \mathrm{~m}$ elevation, though eventual departures from such a pattern due to local particularities should not be excluded (e.g., Ejarque et al., 2010). Further studies should confirm or refute this hypothesis.

\section{Conclusions}

Palynological analyses of varved sediments from Lake Montcortès corresponding to the time interval between the Late Bronze Age (ca. $1100 \mathrm{BCE}$ ) and the Early Medieval period (820 CE) revealed that the most pristine, possibly preanthropic, vegetation and landscape conditions occurred during the Late Bronze Age (ca. 1100 BCE-770 BCE), when the lake was surrounded by riverine forests dominated by Alnus and Corylus. The ultimate anthropization of these landscapes began with the incoming of the Iron Age (770 BCE), when the local vegetation was burnt and the plant cover attained a minimum. This degraded landscape was used for cultivation and grazing until the end of the Iron Age (180 BCE-70 BCE). The beginning of Roman domination (70 BCE-100 CE) was characterized by a relaxation of the human pressure and the return of Corylus stands around the lake, possibly favored by humans. A maximum of local land use, mostly grazing and cereal cultivation occurred later (100 CE-260 CE), followed by a decline in human activities at the end of the Roman period (260 CE-420 CE). During the transition between the Roman and the Early Medieval periods (known as the Migration Period), anthropogenic pressure was decreasing. The maximum human disturbance of the entire record began in Early Medieval times (580 CE onwards) when the plant cover dramatically decreased and the lake catchment was used for the hemp industry until $760 \mathrm{CE}$, and it then transformed into grass meadows. The regional vegetation was dominated by Mediterranean and submontane forests dominated by evergreen and deciduous Quercus species, respectively, until the end of the Iron Age, when montane Pinus forests increased their importance. In the Early Medieval period, the submontane Quercus (deciduous) forests disappeared, possibly due to selective anthropogenic deforestation. In general, human activities have been the major responsible factor for vegetation and landscape transformation in the Montcortès region. Independent studies have demonstrated the occurrence of climatic changes, but the influence of these environmental shifts on the lake watershed have been comparatively lower than anthropic pressure, especially since the Iron Age, when humans began to transform the Montcortès landscape. Regional vegetation could have been more affected by climatic shifts, probably by up and down displacements of Pinus and Quercus forest belts due to temperature changes. The case of Montcortès is relevant because previous studies based on indirect sedimentological proxies seemed to indicate that human impact was low until Medieval times. The same idea has been adopted for the central Pyrenees, in general, where climate has been considered the main driver of vegetation and landscape change until Medieval times, when human activities would have replaced climatic shifts as the controlling factor. In Montcortès, however, the decisive anthropogenic transformation had already occurred a couple of millennia ago, during the early Iron Age. It could be interesting to verify whether the same pattern - i.e., Iron Age anthropization and Early Medieval intensification of human pressure has been a general pattern for mid-elevation Pyrenean landscapes below the tree line. 


\section{Acknowledgments}

Funding agencies: Spanish Ministry of Science and Technology, projects RyC2003 to VR, LIMNOCLIBER (REN2003-09130-C02-02) to BVG and MEDLANT (CGL2016-7215-R) to BVG; Spanish Ministry of Economy and Competitiveness, project MONT-500 (CGL2012-3665) to TVV. European Union MSCA-IF-EF-ST funding scheme, project FLOODARC (796752) to JPC. Fieldwork participants (April 2004): Doug Shnurrenberger, Mark Shapley and Anders Noren (Limnological Research Center, USA); Blas Valero-Garcés, Penélope González-Sampériz and Ana Moreno (Pyrenean Institute of Ecology, Spain); Valentí Rull and Santiago Giralt (Institute of Earth Sciences Jaume Almera, Spain). Fieldwork permits: Territorial Service of the Department of Agriculture, Livestock, Fishing and Natural Environment of Catalonia (Barcelona). Laboratory processing: Núria Cañellas (Laboratory of Paleoecology, Institute of Earth Sciences Jaume Almera). Local collaborators: Council of Baix Pallars (Gerri de la Sal), Xavier Figuera (Montcortès). Historical documentation: Pallars Sobirà District Archive (Sort). 


\section{References}

Bennett KD (1996) Determination of the number of zones in a biostratigraphical sequence. New Phytologist 132: 155-170.

Bennett KD and Willis, KJ (2001) Pollen. In: Smol JP, Birks HJB and Last WM (eds.) Tracking Environmental Change Using Lake Sediments, Volume 3: Terrestrial, Algal, and Siliceous Indicators. Dordrecht: Kluwer, 5-32.

Camps J, Gonzalvo I, Güell J, et al. (1976) El lago de Montcortès, descripción de un ciclo annual. Oecologia Aquatica 2: 99-110.

Carreras J, Vigo J and Ferré A. (2005-2006) Manual dels hàbitats de Catalunya, vols I-VIII. Departament de Medi Ambient i Habitatge, Generalitat de Catalunya, Barcelona.

Catalan J, Pèlachs A, Gassiot E, et al. (2013) Interacción entre clima y ocupación humana en la configuración del paisaje vegetal del Parque Nacional de Aigüestortes i Estany de Sant Maurici a lo largo de los últimos 15.000 años. Proyectos de Investigación en Parques Nacionales: 2009-2012, Organismo Autónomo de Parques Nacionales, Madrid, 71-92.

Clop X and Faura JM (1995) La Cabana de Perauba (Peracalç, Pallars Sobirà) I el megalitisme al Pallars. Revista d'Arqueologia de Ponent 5: 127-142.

Corella JP, Moreno A, Morellón, M, et al. (2011a) Climate and human impact on a meromictic lake during the last 6,000 years (Montcortès Lake, Central Pyrenees, Spain). Journal of Paleolimnology 46: 351-367.

Corella JP, El Amrani A and Sigró J, et al. (2011b) Recent evolution of Lake Arreo, northern Spain: influences of land use and climate change. Journal of Paleolimnology 46: 469-485.

Corella JP, Brauer A, Mangili C, et al. (2012) The 1.5-ka varved record of Lake Montcortès (southern Pyrenees, NE Spain). Quaternary Research 78: 323-332.

Corella JP, Stefanova V, El Anjoumi A, et al. (2013) A 2500-year multi-proxy reconstruction of climate change and human activities in northern Spain: the Lake Arreo record. Palaeogeography Palaeoclimatology Palaeoecology 386: 555-568.

Corella JP, Benito G, Rodriguez-Lloveras X, et al. (2014) Annually-resolved lake record of extreme hydro-meteorological events since AD 1347 in NE Iberian Peninsula. Quaternary Science Reviews 93: 77-90.

Corella JP, Valero-Garcés BL, Vicente-Serrano SM, et al. (2016) Three millennia of heavy rainfalls in Western Mediterranean: frequency, seasonality and atmospheric drivers. Scientific Reports 6: 38206.

Corella JP, Valero-Garcés BL, Wang F, et al. (2017) 700 years reconstruction of mercury and lead atmospheric deposition in the Pyrenees (NE Spain). Atmospheric Environment 155: 97107.

Corella JP, Benito G, Wilhelm B, et al. (2019) A millennium-long perspective of flood-related seasonal sediment yield in Mediterranean watersheds. Global and Planetary Change 177: 127-140.

Cots P (2005) Els pobles de la prehistòria I l'antiguitat. In: Marugan CM and Rapalino V (eds.) Història del Pallars. Dels orígens als nostres dies. Lleida: Pagès Editors, 13-43.

Dubois H, Verkasalo E and Claessens H (2020) Potential of Birch (Betula pendula Roth and B. pubescens Ehrh.) for forestry and forest-based industry sector within the changing climate and socio-economic context of western Europe. Forests 11: 336.

Ejarque A, Miras Y, Riera S, et al. (2010) Testing micro-regional variability in the Holocene shaping of high mountain cultural landscapes: a palaeoenvironmental case-study in the eastern Pyrenees. Journal of Archaeological Science 37: 1468-1479.

Esteban A (2003) La Humanización de las Altas Cuencas de la Garona y las Nogueras (4500 aC1955 aC). Organismo Autónomo de Parques Nacionales, Ministerio del Medio Ambiente, Madrid.

Folch R, Franquesa E and Camarasa JM (1984) Història Natural dels Països Catalans. Vol. 7, Vegetació. Barcelona: Enciclopèdia Catalana. 
García-Ruiz JM, Tomás-Faci G, Diarte-Blasco P, et al. (2020) Transhumance and long-term deforestation in the subalpine belt of the central Spanish Pyrenees: an interdisciplinary approach. Catena 195: 104744.

Gassiot E and Pèlachs A (2017) La ocupación ganadera de los Pirineos occidentales de Catalunya en época romana e inicios de la Edad Media. Treballs d'Arqueologia 21: 287306.

Gassiot E, Mazzucco N, Clemente I, et al. (2017) The beginning of high mountain occupations in the Pyrenees. Human settlements and mobility from 18,000 cal BC to $2000 \mathrm{cal}$ BC. In: Catatan J, Ninot JM and Aniz M (eds.) High-Mountain Conservation in a Changing World. Berlin, Springer, 75-105.

González-Sampériz P, Aranbarri J, Pérez-Sanz A, et al. (2017) Environmental and climate change in the southern Central Pyrenees since the Last Glacial Maximum: a review from the lake records. Catena 149: 668-688.

González-Sampériz P, Montes L, Aranbarri J, et al. (2019) Escenarios, tiempo e indicadores paleoambientales para la identificación del Antropoceno en el paisaje vegetal del Pirineo central (NE Iberia). Cuadernos de Investigación Geográfica 45: 167-193.

Gutiérrez F, Linares R, Roqué $C$, et al. 2012. Investigating gravitational grabens related to lateral spreading and evaporite dissolution subsidence by means of detailed mapping, trenching, and electrical resistivity tomography. Lithosphere 4: 331-353.

Martín-Chivelet J, Muñoz-García MB, Edwards RL, et al. (2011) Land surface temperature changes in Northern Iberia since $4000 \mathrm{yr}$ BP, based on $\delta^{13} \mathrm{C}$ of speleothems. Global and Planetary Change 77: 1-12.

Martín-Puertas C, Valero-Garcés BL, Brauer, A, et al. (2009) The Iberian-Roman Humid Period (2600-1600 cal yr BP) in the Zoñar Lake varve record (Andalucía, southern Spain). Quaternary Research 71: 108-120.

Martín-Puertas C, Jiménez-Espejo F, Martínez-Ruiz F, et al. (2010) Late Holocene Variability in the southwestern Mediterranean region: an integrated marine and terrestrial geochemical approach. Climate of the Past 6: 807-816.

Marugan CM and Oliver J (2005) El Pallars Medieval. In: Marugan CM and Rapalino V (eds.) Història del Pallars. Dels Orígens als Nostres Dies. Lleida: Pagès Editors, 45-86.

Marugan CM and Rapalino V (2005) Història del Pallars. Dels Orígens als Nostres Díes. Lleida, Pagès Editors.

Mercadé A, Vigo J, Rull V, et al. 2013. Vegetation and landscape arounf Lake Montcortès (Catalan pre-Pyrenees) as a tool for palaeoecological studies of lake sediments. Colectanea Botanica 32: 87-101.

Modamio X, Pérez V and Samarra F (1988) Limnología del lago de Montcortès (ciclo 19781979). Oecologia Aquatica 9: 9-17.

Montoya E, Rull V, Vegas-Vilarrúbia T, et al. 2018. Grazing activities in the southern central Pyrenees during the last millennium as deduced from the non-pollen palynomorphs (NPP) record of Lake Montcortès. Review of Palaeobotany and Palynology 254: 8-19.

Moore PD, Webb JA and Collinson ME 1991. Pollen Analysis. Oxford: Blackwell.

Morellón M, Anselmetti FS, Valero-Garcés B, et al. (2015) Local formation of varved sediments in a karstic collapse depression of Lake Banyoles (NE Spain). Geogaceta 57: 119-122.

Moreno A, Pérez A, Frigola J, et al. 2012. The medieval climate anomaly in the Iberian Peninsula reconstructed from marine and lake records. Quaternary Science Reviews 43: 16-32.

Obea L, Celma M, Piqué R, et al. (2020) Firewood-gathering strategies in high mountain areas of the Parc Nacional d'Aigüestortes I Estany de Sant Maurici (central Pyerenees) during prehistory. Quaternary International, doi 10.1016/j.quaint.2020.11.044

Oliva M, Ruiz-Fernández J, Barriendos M, et al. (2018) The Little Ice Age in Iberian mountains. Earth-Science Reviews 177: 175-208. 
Ojala AE, Saarinen T and Salonen VP (2000) Preconditions for the formation of annually laminated lake sediments in southern and central Finland. Boreal Envornmental Research 5: $143-255$.

O'Sullivan PE (1983) Annually-laminated lake sediments and the study of Quaternary environmental changes - a review. Quaternary Science Reviews 43: 45-60.

Panyella A (1944) La Pleta de Compte en Peramea. Ampurias 6: 69-86.

Pèlachs A, Pérez-Obiol R, Ninyerola M, et al. (2009) Landscape dynamics of Fagus and Abies in the southern Pyrenees during the last 2200 years as a result of human impact. Review of Palaeobotany and Palynology 156: 337-349.

Peña-Chocarro L, Pérez-Jordà G, Alonso N, et al. (2019) Roman and medieval crops in the Iberian Peninsula: a first overview of seeds and fruits from archaeological sites. Quaternary International 499: 49-66.

Piera M (2013) El Pla de la Guineu (Gerri de la Sal): primeres evidències d'explotació de la sal en època del bronze. Primeres Jornades d'Arqueologia i Paleontologia del Pirineu i Aran, Coll de Nargó-La Seu d'Urgell, November 2013, pp. 52-57.

Piera M, Pancorbo A, Garcés I, et al. (2013) Els assentaments de les edats del bronze, ibèrica I romana dels Llirians del Mas I les Torres (Salàs de Pallars, Pallars Jussà). Revista d'Arqueologia de Ponent 23: 163-200.

Ramisch A, Brauser A, Dorn M, et al. (2020) VARDA (VARved sedimentss DAtabase) - providing and connecting proxy data from annually laminated lake sediments. Earth System Science Data 12: 2311-2332.

Rodríguez D, Gassiot E, Mazzucco N, et al. 2016. Del medio natural a los paisajes pastorales. Ocupación de las zonas de alta montaña en los Pirineos centrales de Cataluña desde el Mesolítico a la Edad del Bronce (c. 9000-1000 cal ANE). Munibe Anthropologia-Arkeologia 67: 325-337.

Romero-Viana L, Juliá R, Camacho A, et al. (2008) Climate signal in varve thickness: Lake La Cruz (Spain), a case study. Journal of Paleolimnology 40: 703-714.

Rull V (1987) A note on pollen counting in paleoecology. Pollen Spores 29: 471-480.

Rull V (2014) Time continuum and true long-term ecology: from theory to practice. Frontiers in Ecology and Evolution 2: 75.

Rull V and Vegas-Vilarrúbia T (2014) Preliminary report on a mid-19 ${ }^{\text {th }}$ century Cannabis pollen peak in NE Spain: historical context and potential chronological significance. Holocene 24: 1378-1383.

Rull V and Vegas-Vilarrúbia T (2015) Crops and weeds from the Estany de Montcortès catchment, central Pyrenees, during the last millennium: a comparison of palynological and historical records. Vegetation History and Archaeobotany 24: 699-710.

Rull V, González-Sampériz P, Corella JP, et al. 2011. Vegetation changes in the southern Pyrenean flank during the last millennium in relation to climate and human activities: the Montcortès lacustrine record. Journal of Paleolimnology 46: 387-404.

Rull V, Trapote MC, Safont E, et al. 2017. Seasonal patterns of pollen sedimentation in Lake Montcortès (Central Pyrenees) and potential applications to high-resolution paleoecology: a 2-year pilot study. Journal of Paleolimnology 57: 96-108.

Scussolini P, Vegas-Vilarrúbia T, Rull V, et al. (2011) Middle and Late Holocene climate change and human impact inferred from diatoms, algae and aquatic macrophyte pollen in sediments from Lake Montcortès (NE Iberian Peninsula). Journal of Paleolimnology 46: 369-385.

Simon $\mathrm{M}$ and Vicente $\mathrm{O}$ (2002) Noves dades sobre el poblament de finals del III mil.leni Cal BC a la Serra Magdalena (Pallars Sobirà, Lleida). XII Col-loqui Internacional d'Arqueologia de Puigcerdà, Puigcerdà 2002, pp. 207-218.

Stephens L, Fuller D, Boivin N, et al. 2019. Archaeological assessment reveals Earth's early transformation through land use. Science 365: 897-902. 
Trapote MC, Vegas-Vilarrúbia T, López P, et al. (2018a) Modern sedimentary analogues and integrated monitoring to understand varva formation in the Mediterranean Lake Montcortès (Central Pyrenees, Spain). Palaeogeography, Palaeoclimatology, Palaeoecology 496: 292-304.

Trapote MC, Rull V, Giralt S, et al. 2018b. High-resolution (sub-decadal) pollen analysis of varved sediments from Lake Montcortès (souther Pyrenean flank): a fine-tuned record of landscape dynamics and human impact during the last 500 years. Review of Palaeobotany and Palynology 259: 207-222.

Valero-Garcés BL and Corella JP 2018. Varve chronology. Encyclopedia of Archaeological Sciences: 1-4.

Vegas-Vilarrúbia T, Corella JP, Pérez-Zanón N, et al. (2018) Historical shifts in oxygenation regime as recorded in the laminated sediments of Lake Montcortès (Central Pyrenees) support hypoxia as a continental-scale phenomenon. Science of the Total Envrionment 612: 1577-1592.

Vegas-Vilarrúbia T, Rull V, Trapote MC, et al. (2020) Modern analogue approach applied to high-resolution varved sediments - a synthesis for Lake Montcortès (Central Pyrenees). Quaternary 3, 1.

Vigo J and Ninot J 1987. Los Pirineos. In: Peinado M and Rivas-Martínez F (eds.) La Vegetación de España. Madrid: Universidad de Alcalá de Henares, 349-384.

Zolitschka B, Francus P, Ojala AEK, et al. (2015) Varves in lake sediments-a review. Quaternary Science Reviews 117: 1-41. 


\section{Figure captions}

Figure 1. Location map. A) Map of the Iberian Peninsula indicating the locations of lakes with varved sediments in some part of the Holocene record. A - Arreo (Corella et al., 2011b, 2013), B - Banyoles (Morellón et al., 2015), LC - La Cruz (Romero-Viana et al., 2008), M - Montcortès (Corella et al., 2012, 2014), Z - Zóñar (Martín Puertas et al., 2009). Lake Montcortès is highlighted in red. B) Topographic map showing the location of Lake Montcortès (black box) and the surrounding villages (modified from Rull et al., 2017).

Figure 2. Graphic summary of the main paleoclimatic and paleoecological results obtained to date in the varved sediments of Lake Montcortès compared with the historical periods of the Pallars region, where Lake Montcortès is situated, and the climatic phases defined for the Iberian Peninsula.

Figure 3. Lake Montcortès and surroundings. A) General view of the lake facing SW, in autumn 2018. Deciduous trees around the lake correspond to Quercus pubescens/Q. subpyrenaica forest stands, with some intermingled Quercus rotundifolia (evergreen). The evergreen forests in the background mountains are dominated by Pinus spp. (Photo: V. Rull). B) Lake surroundings showing the extensive mixed forests dominated by the evergreen Pinus spp. and Quercus rotundifolia (green) and the deciduous Q. pubescens/Q. subpyrenaica (brown) (Photo: $\mathrm{V}$. Rull). C) High-resolution bathymetry of the lake showing the cores used in this study (modified from Corella et al., 2019).

Figure 4. Age-depth model using the composite depth of the three drives sampled and the varve ages of Corella et al. $(2016,2019)$. The ages of the samples from the base of drive MON04-4A-1K-5 (red dots) were extrapolated assuming the same linear accumulation rates of the overlying samples, which yielded an age of approximately $1100 \mathrm{BCE}$ (3050 yr BP) for the base of the sequence.

Fig. 5. Pollen diagram of Lake Montcortès for the time interval between the Late Bronze Age and the Early Medieval period. Only taxa situated at the left side of the summary column are included in the pollen sum. Sedimentary units according to Corella et al. (2019): Unit 4 biogenic varves with frequent turbidites; Unit 5 - biogenic varves without turbidites; Unit 6 nonbiogenic laminations.

Figure 6. Comparison of the results obtained in this study with the main human developments of the Pallars region and the previous paleoenvironmental studies on Lake Montcortès sediments. The sedimentary units are the same as in Fig. 5. The paleotemperature trends for northern Iberia are based on $\delta^{13} \mathrm{C}$ content in speleothems. IACP - Iron Age Cold Period; RWP Roman Warm Period; DACP - IRHP - Ibero-Roman Humid Period; Dark Ages Cold Period; LALIA - Late Antique Little Ice Age; MWP - Medieval Warm Period.

Figure 7. Hypothetical temporal anthropization trend with time and elevation in the southerncentral Pyrenees, using the available paleoecological studies of lake sediments compiled by Gonzáez-Sampériz et al. $(2017,2019)$ ), complemented with a subalpine lake (Catalan et al., 2013) and a montane peat bog (Pèlachs et al., 2009). The approximate elevations of the lakes studied are marked by blue dots, and Lake Montcortès is highlighted in red. 

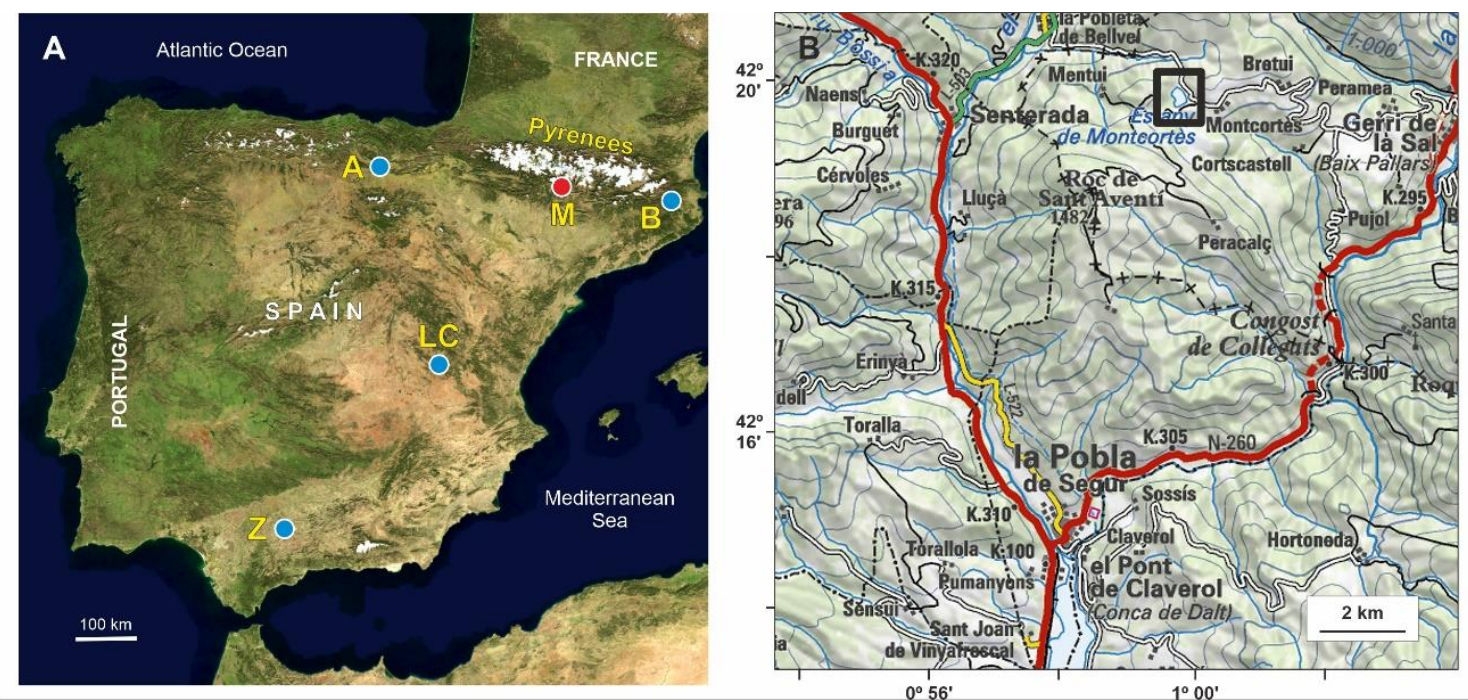

Figure 1

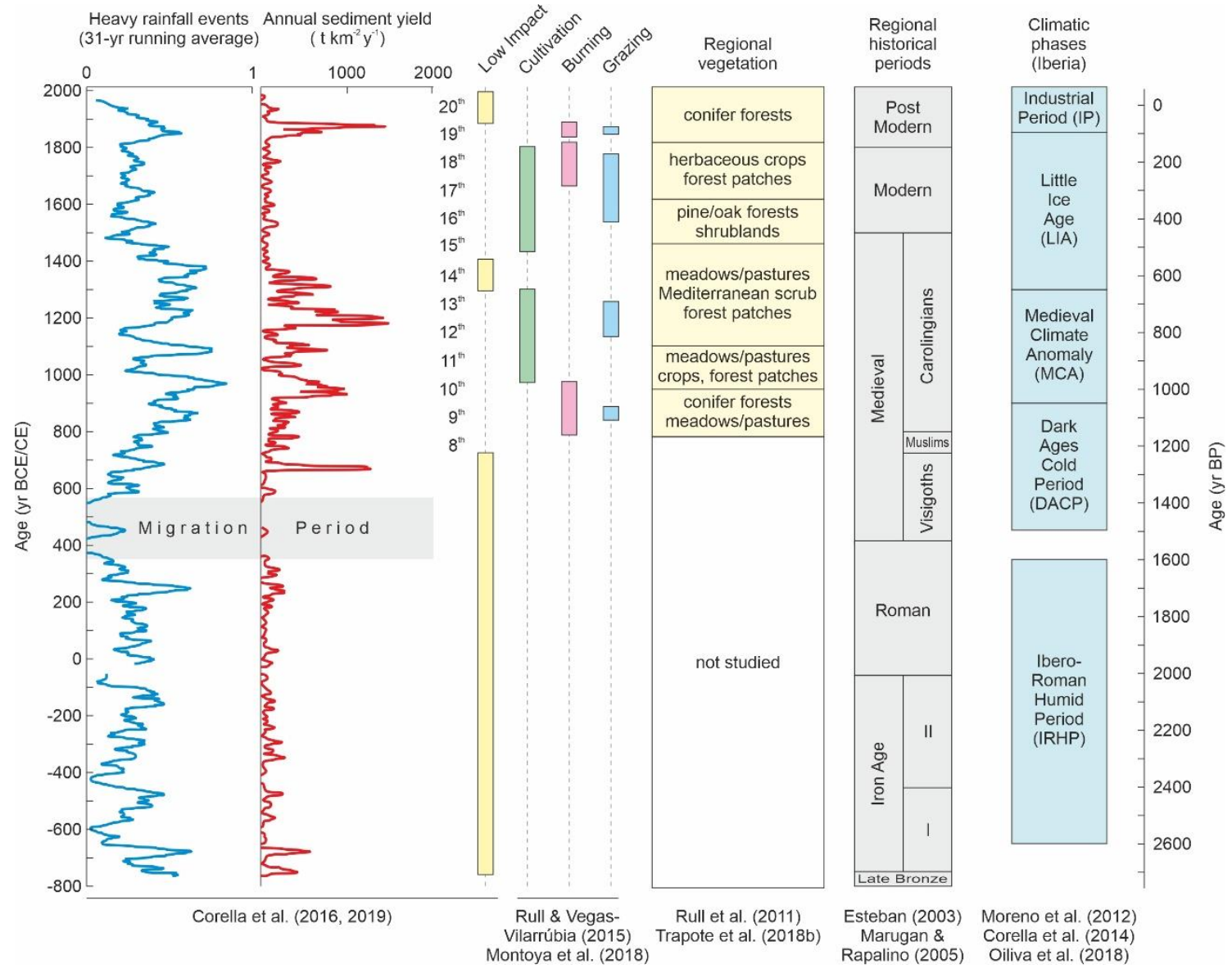

Figure 2 

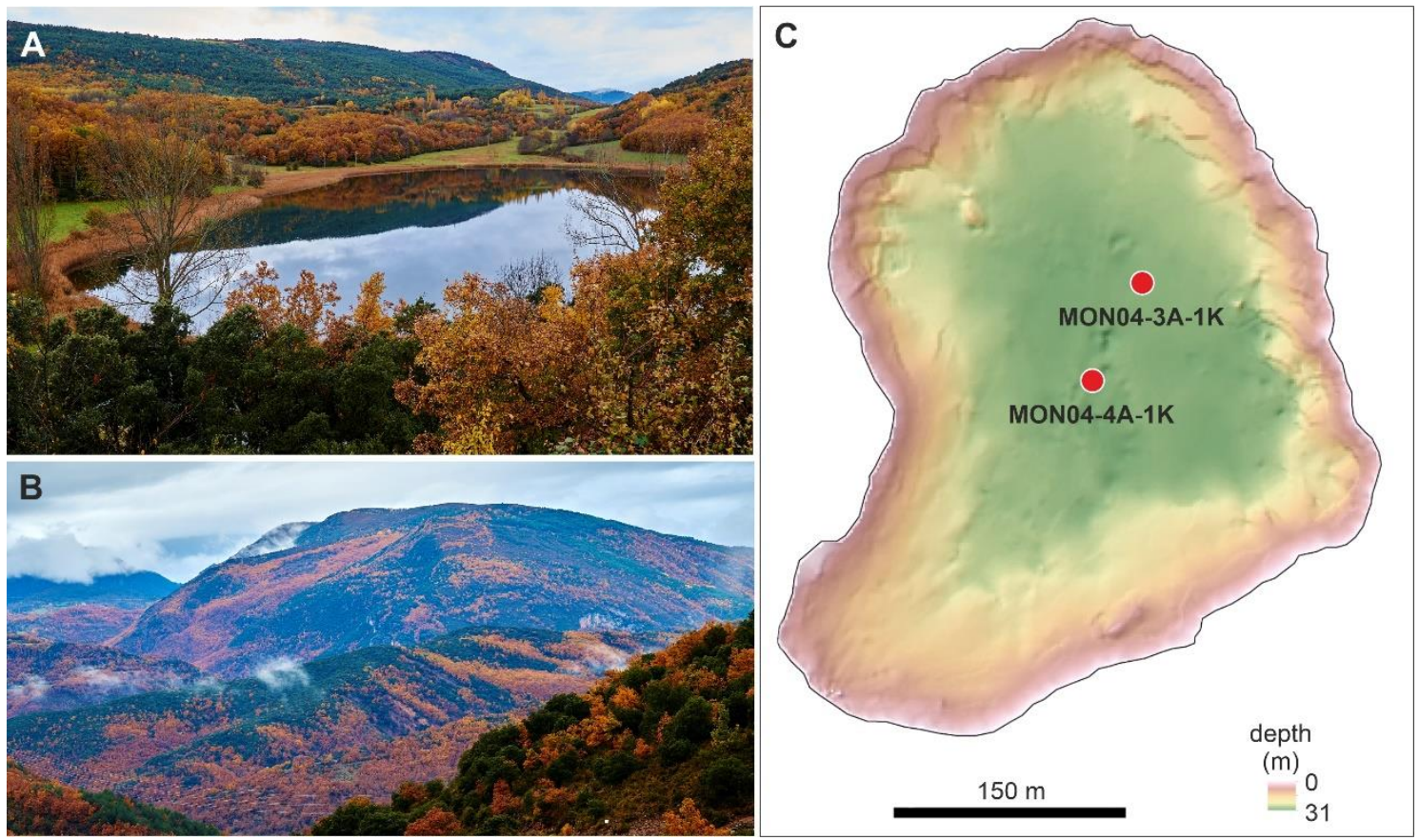

Figure 3

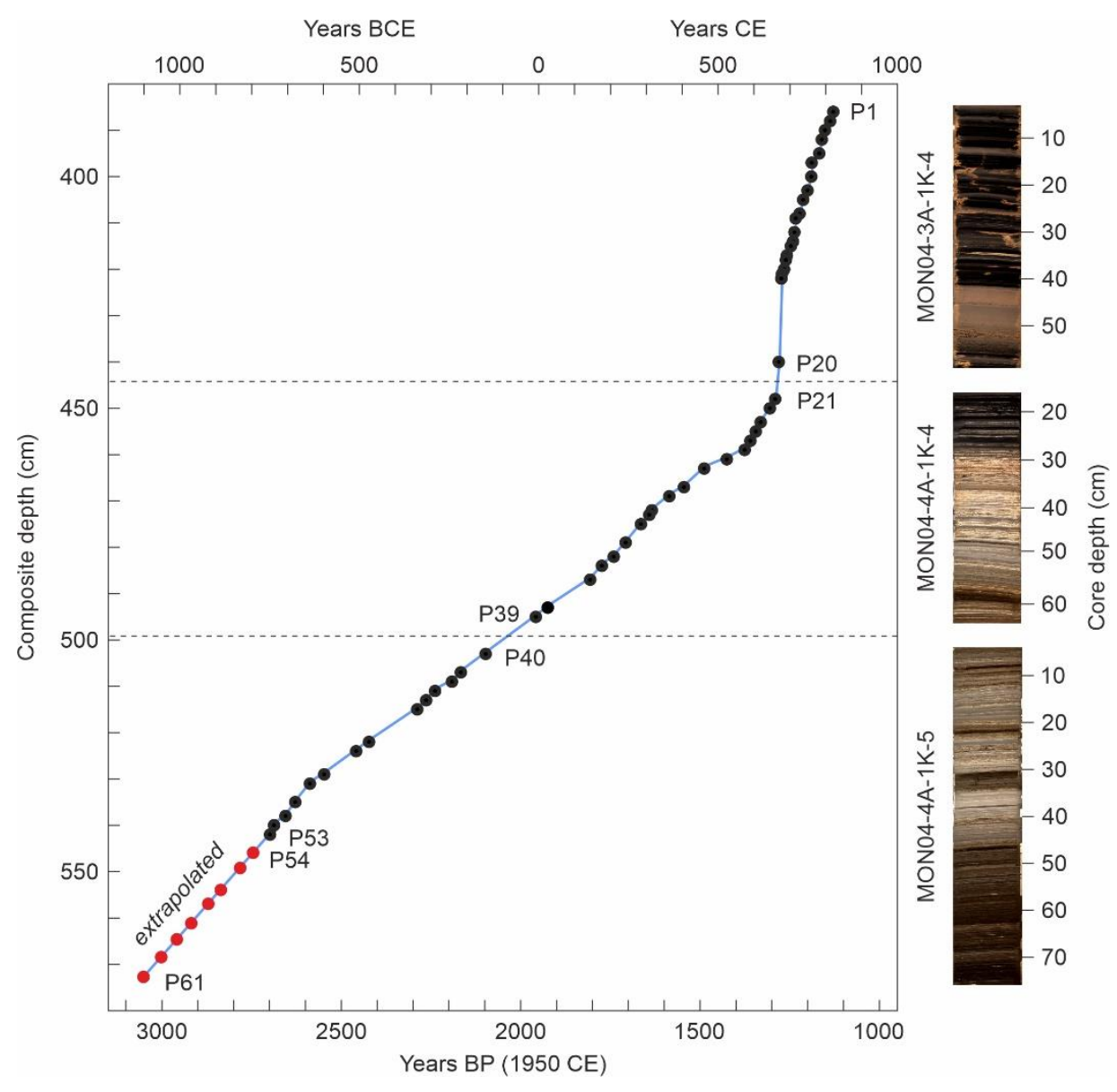

Figure 4 


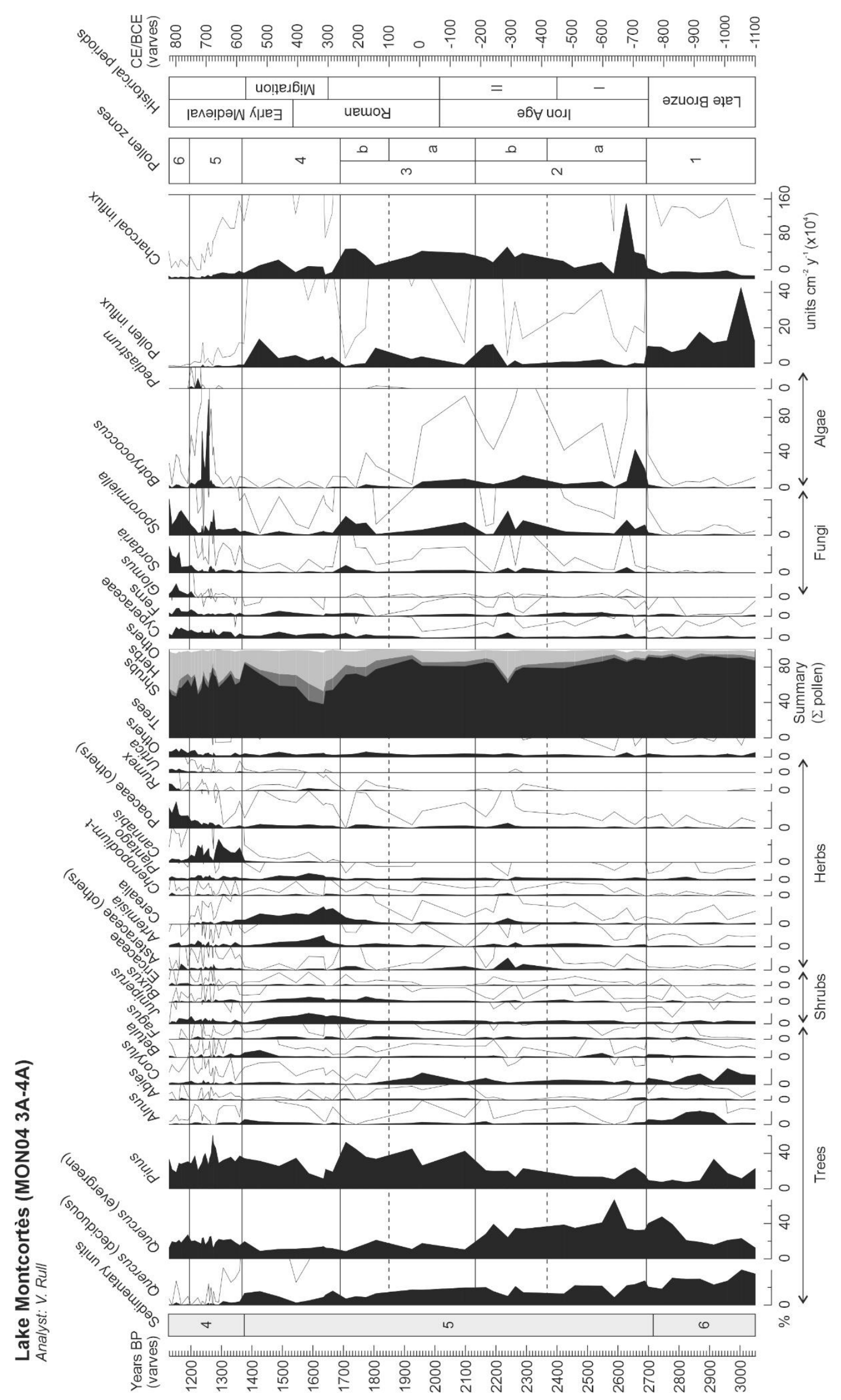

Figure 5 


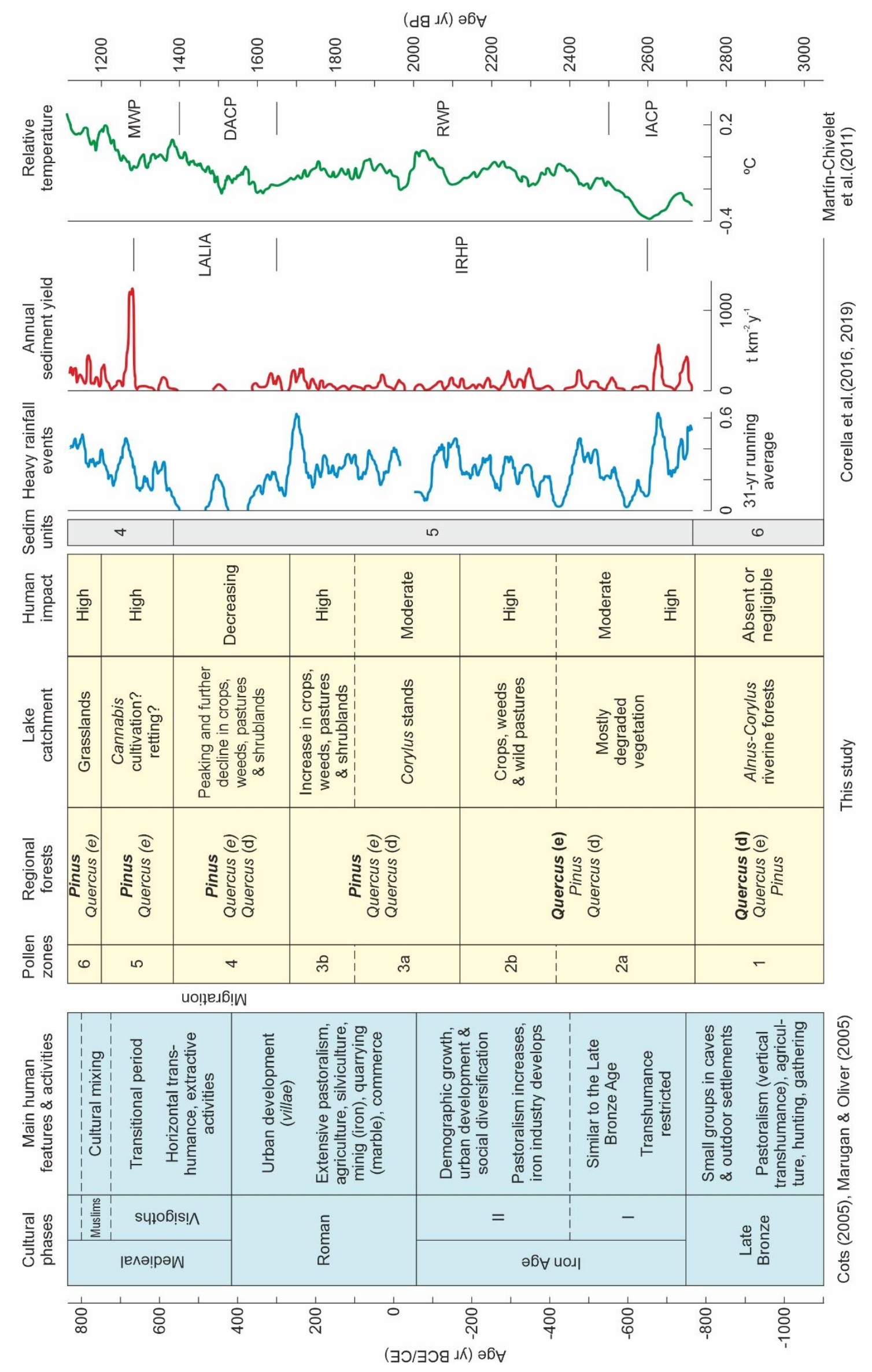

Figure 6 
Temporal anthropization trend

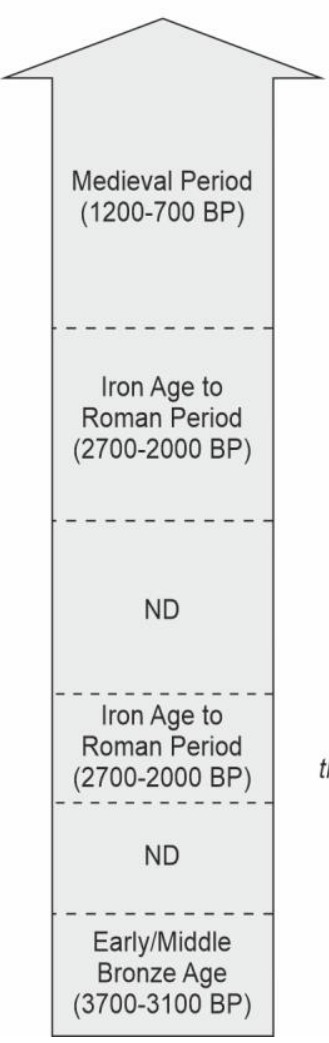

Southern-central

Pyerees

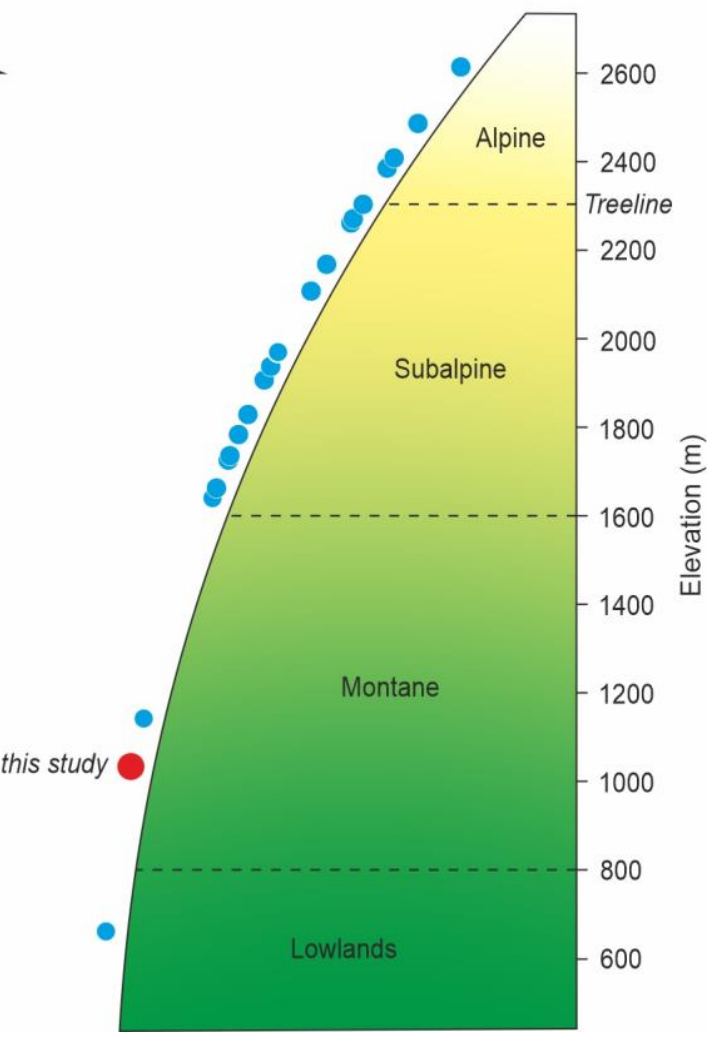

Figure 7 


\section{Figures}
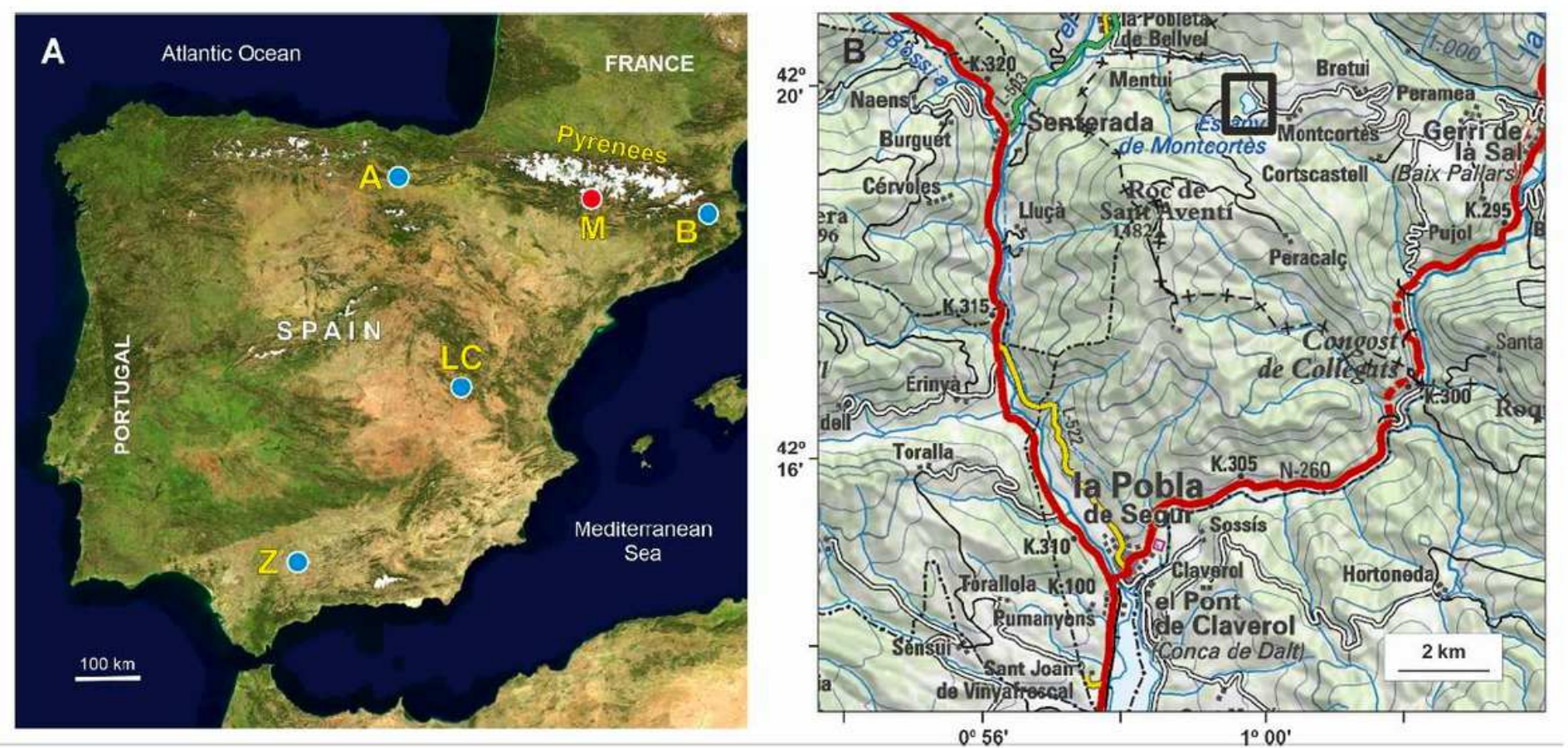

\section{Figure 1}

Location map. A) Map of the Iberian Peninsula indicating the locations of lakes with varved sediments in some part of the Holocene record. A - Arreo (Corella et al., 2011b, 2013), B - Banyoles (Morellón et al., 2015), LC - La Cruz (Romero-Viana et al., 2008), M - Montcortès (Corella et al., 2012, 2014), Z - Zóñar (Martín Puertas et al., 2009). Lake Montcortès is highlighted in red. B) Topographic map showing the location of Lake Montcortès (black box) and the surrounding villages (modified from Rull et al., 2017). 


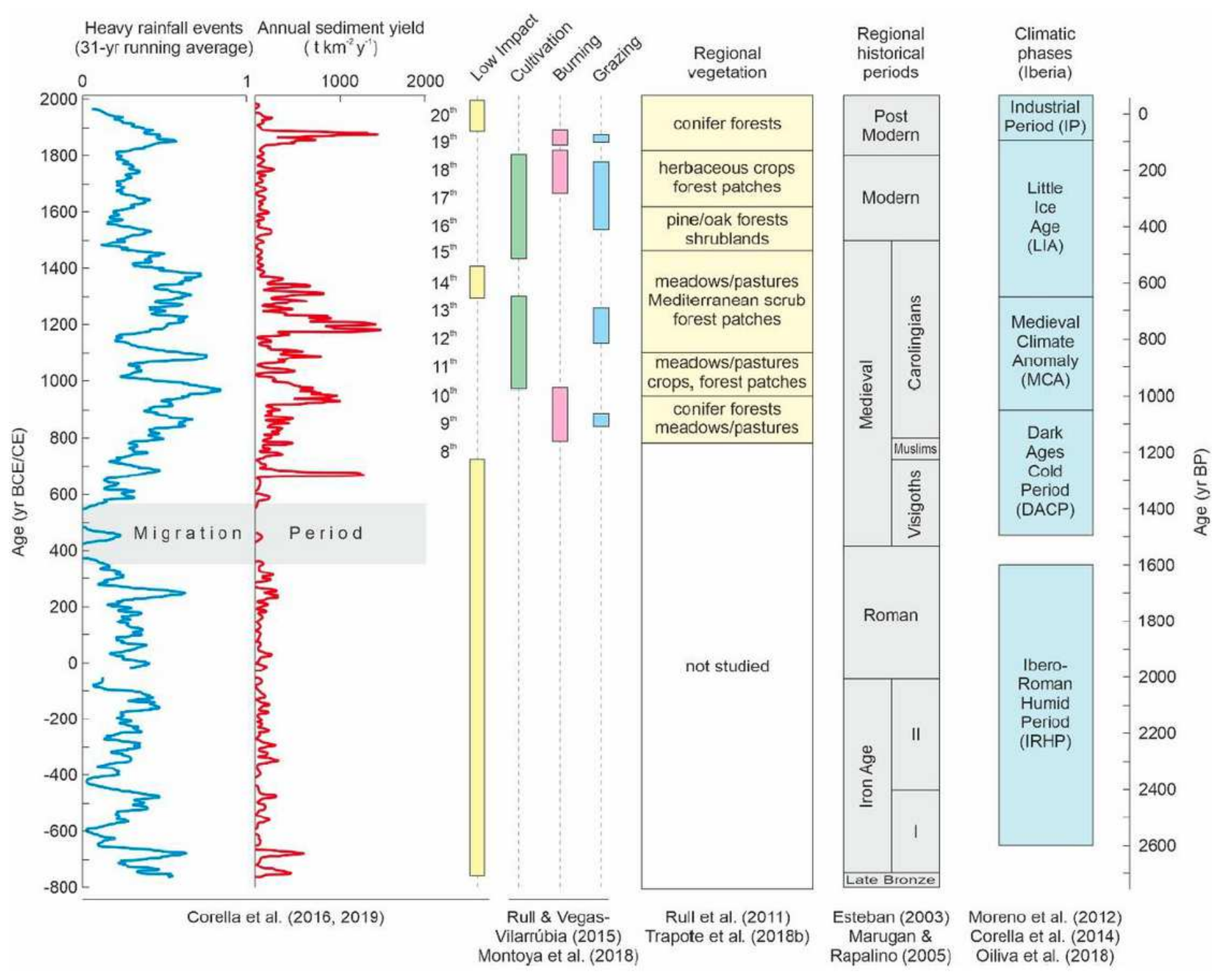

Figure 2

Graphic summary of the main paleoclimatic and paleoecological results obtained to date in the varved sediments of Lake Montcortès compared with the historical periods of the Pallars region, where Lake Montcortès is situated, and the climatic phases defined for the Iberian Peninsula. 

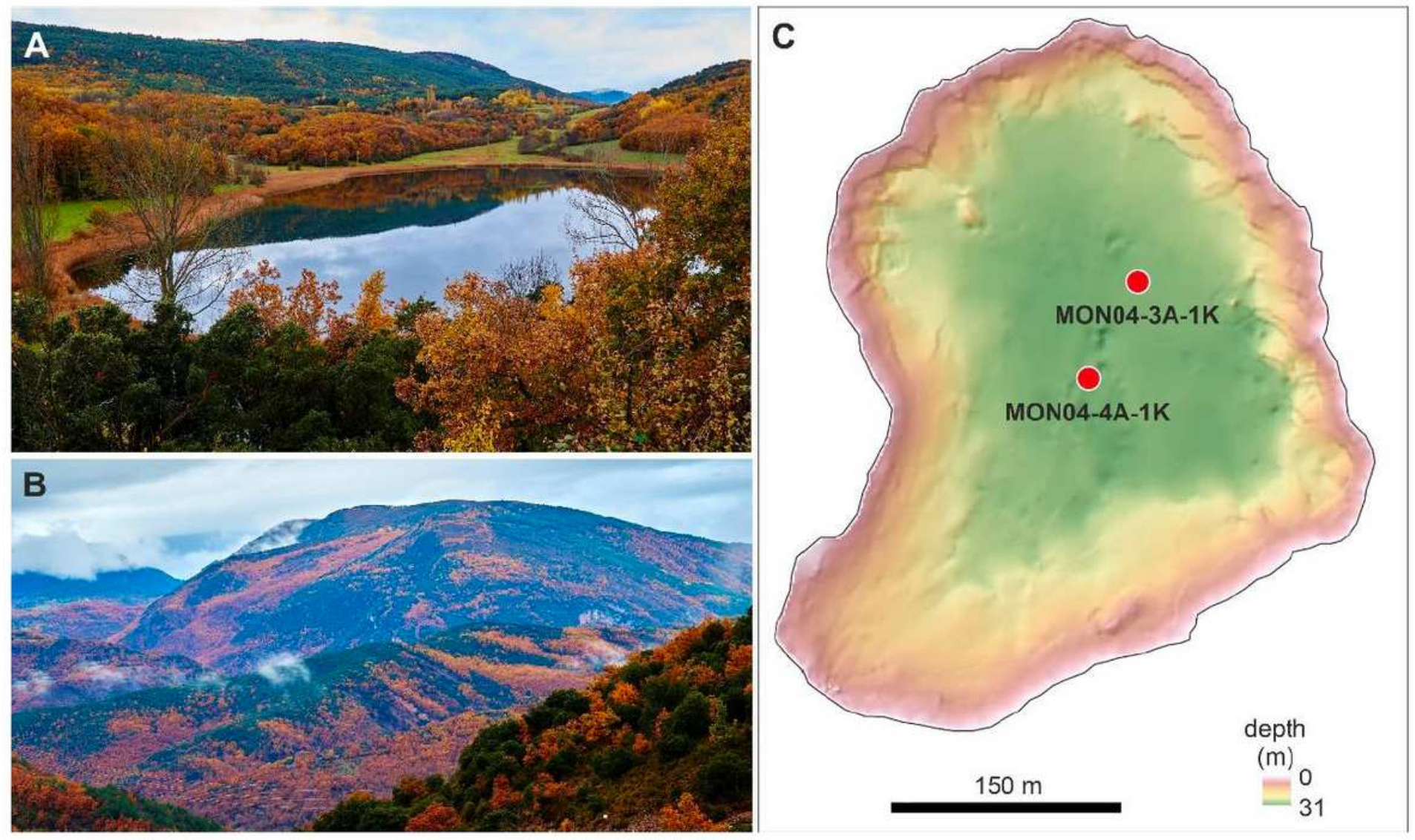

\section{Figure 3}

Lake Montcortès and surroundings. A) General view of the lake facing SW, in autumn 2018. Deciduous trees around the lake correspond to Quercus pubescens/Q. subpyrenaica forest stands, with some intermingled Quercus rotundifolia (evergreen). The evergreen forests in the background mountains are dominated by Pinus spp. (Photo: V. Rull). B) Lake surroundings showing the extensive mixed forests dominated by the evergreen Pinus spp. and Quercus rotundifolia (green) and the deciduous Q. pubescens/Q. subpyrenaica (brown) (Photo: V. Rull). C) High-resolution bathymetry of the lake showing the cores used in this study (modified from Corella et al., 2019). 


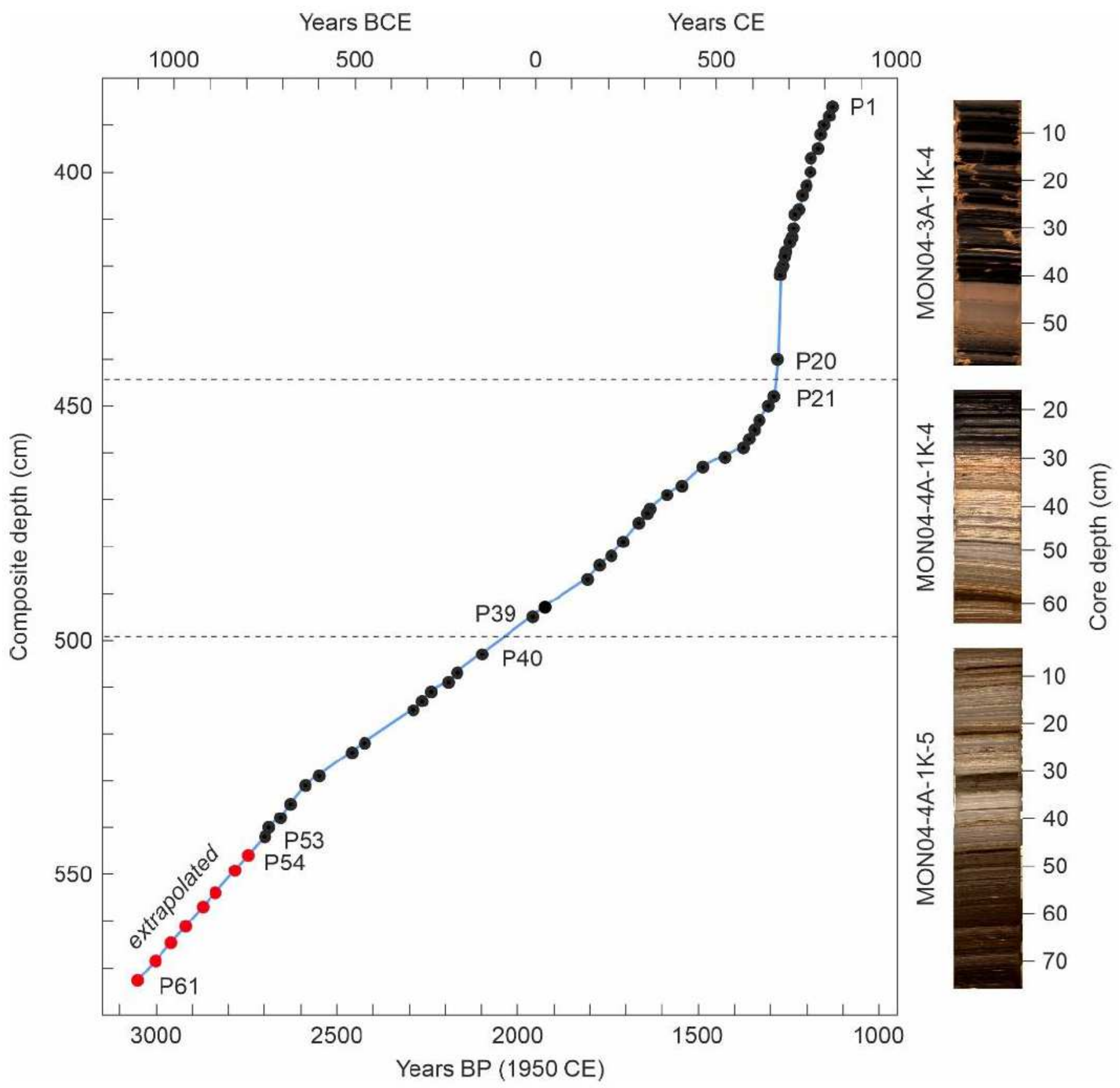

Figure 4

Age-depth model using the composite depth of the three drives sampled and the varve ages of Corella et al. $(2016,2019)$. The ages of the samples from the base of drive MON04-4A-1 K-5 (red dots) were extrapolated assuming the same linear accumulation rates of the overlying samples, which yielded an age of approximately 1100 BCE (3050 yr BP) for the base of the sequence. 
Lake Montcortès (MON04 3A-4A)

Analyst: V. Rull

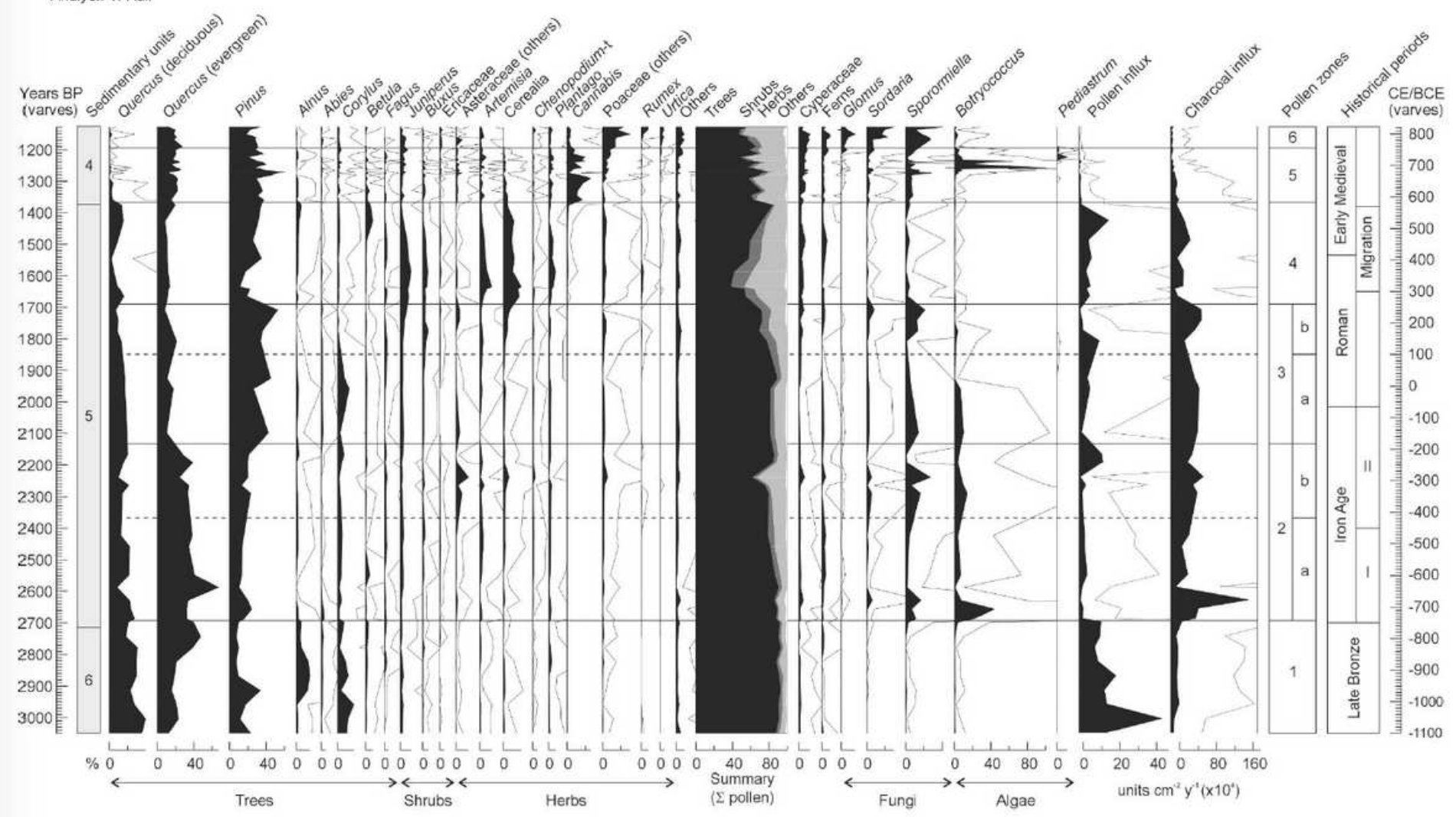

Figure 5

Pollen diagram of Lake Montcortès for the time interval between the Late Bronze Age and the Early Medieval period. Only taxa situated at the left side of the summary column are included in the pollen sum. Sedimentary units according to Corella et al. (2019): Unit 4 - biogenic varves with frequent turbidites; Unit 5 - biogenic varves without turbidites; Unit 6 - nonbiogenic laminations. 


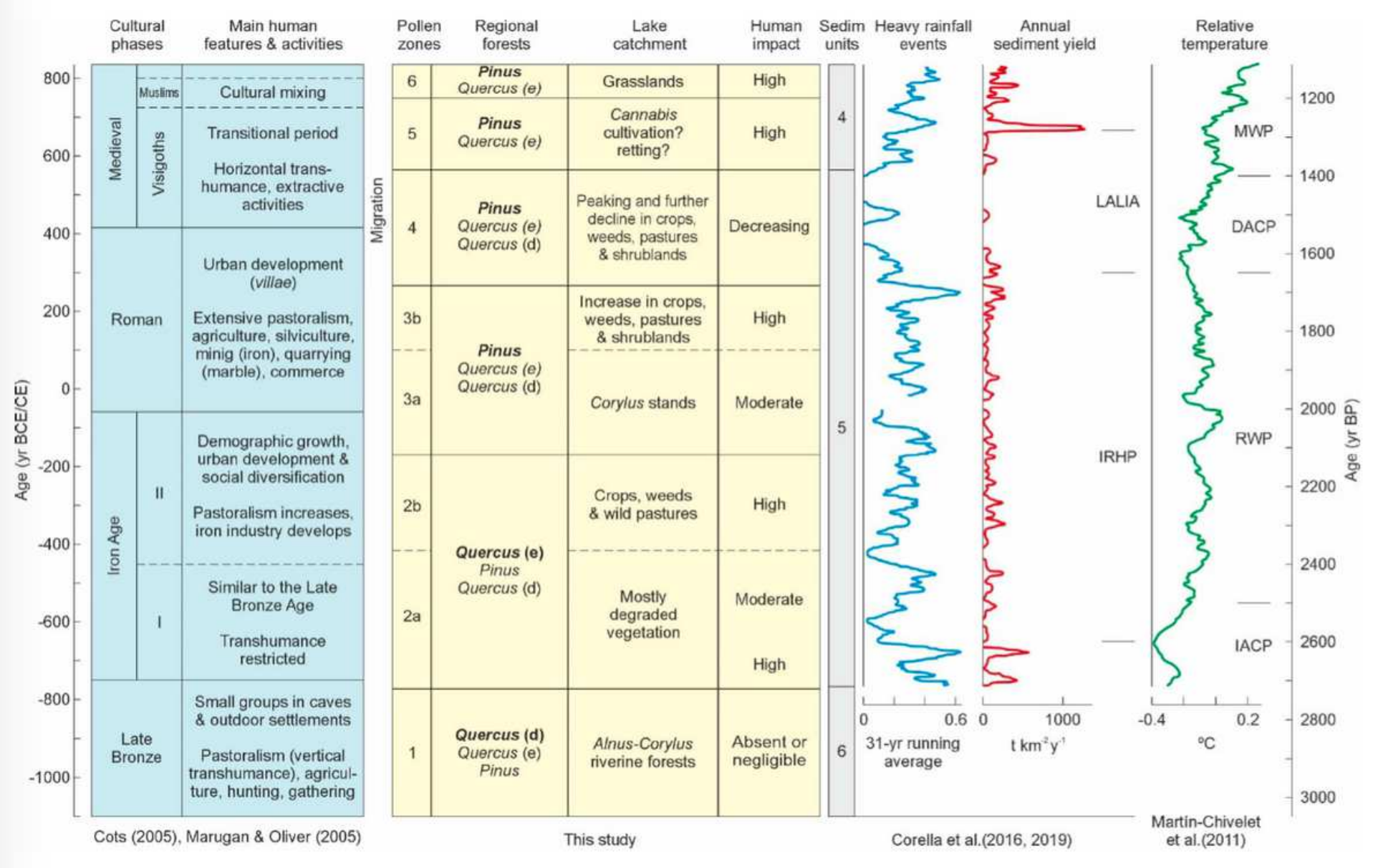

\section{Figure 6}

Comparison of the results obtained in this study with the main human developments of the Pallars region and the previous paleoenvironmental studies on Lake Montcortès sediments. The sedimentary units are the same as in Fig. 5. The paleotemperature trends for northern Iberia are based on $813 \mathrm{C}$ content in speleothems. IACP - Iron Age Cold Period; RWP - Roman Warm Period; DACP - IRHP - Ibero-Roman Humid Period; Dark Ages Cold Period; LALIA - Late Antique Little Ice Age; MWP - Medieval Warm Period. 


\section{Temporal anthropization trend}

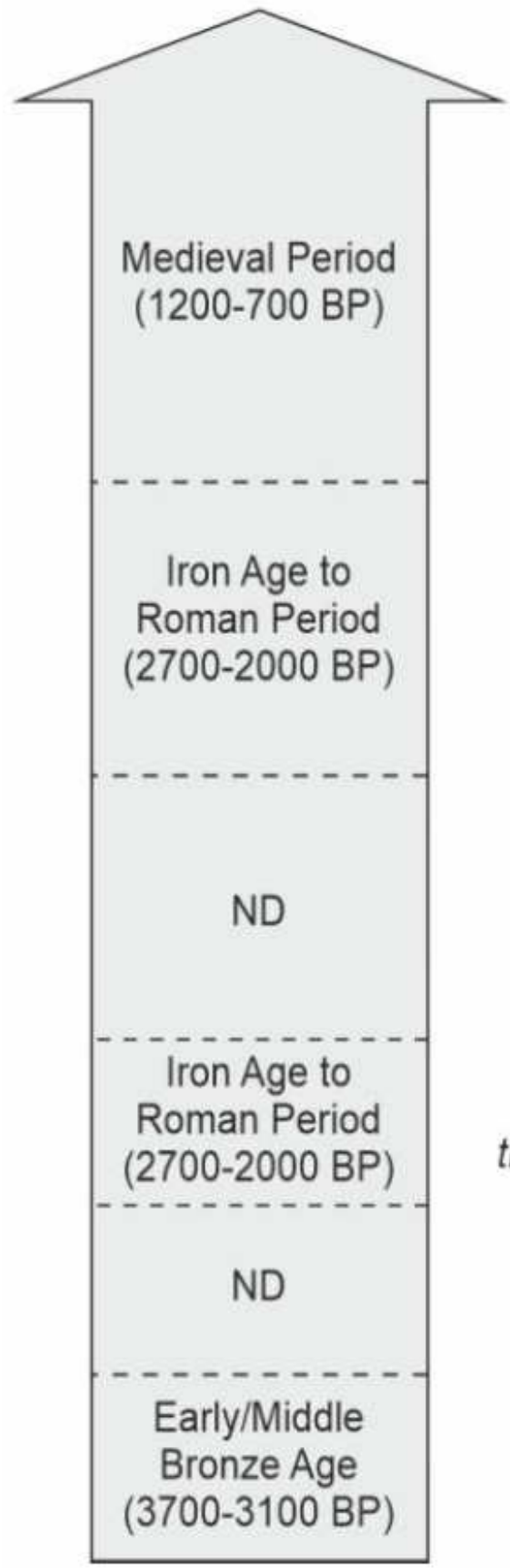

\section{Southern-central}

Pyerees

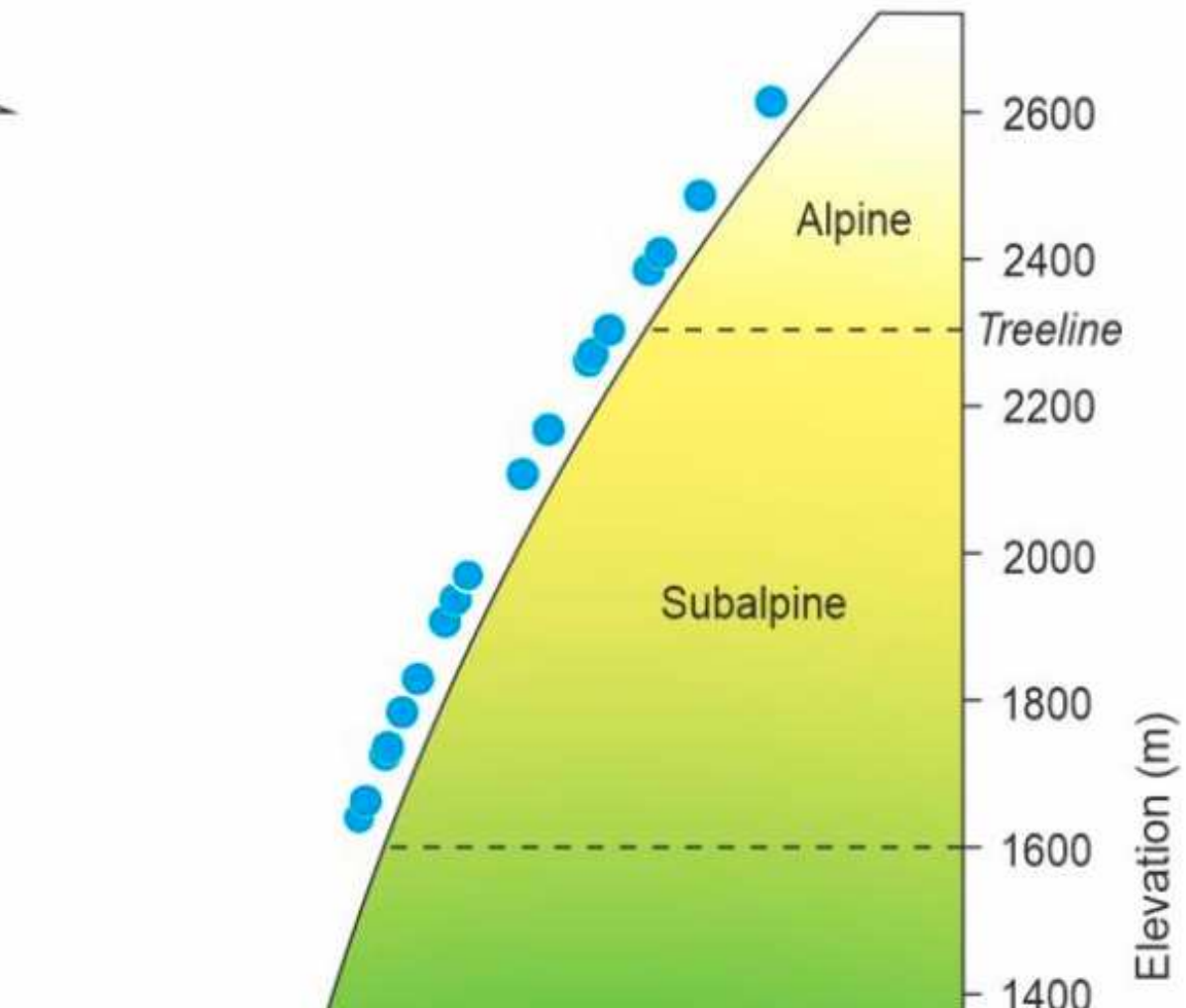

this study

1400

Montane

1200

1000

800

600

\section{Figure 7}

Hypothetical temporal anthropization trend with time and elevation in the southern-central Pyrenees, using the available paleoecological studies of lake sediments compiled by Gonzáez-Sampériz et al. $(2017,2019)$ ), complemented with a subalpine lake (Catalan et al., 2013) and a montane peat bog (Pèlachs et al., 2009). The approximate elevations of the lakes studied are marked by blue dots, and Lake Montcortès is highlighted in red. 